OPEN ACCESS

Edited by:

Alberto Perez-Huerta, The University of Alabama,

United States

Reviewed by:

Alexey Kamyshny,

Ben-Gurion University of the Negev,

Israel

William Patrick Gilhooly III, Purdue University Indianapolis,

United States

*Correspondence:

Adam Levi

adam.levi@mail.huji.ac.ll

Specialty section:

This article was submitted to Biogeoscience,

a section of the journal

Frontiers in Earth Science

Received: 06 February 2019

Accepted: 04 September 2019

Published: 04 October 2019

Citation:

Levi A, Müller W and Erez J (2019) Intrashell Variability of Trace Elements in Benthic Foraminifera Grown Under High $\mathrm{CO}_{2}$ Levels.

Front. Earth Sci. 7:247. doi: 10.3389/feart.2019.00247

\section{Intrashell Variability of Trace Elements in Benthic Foraminifera Grown Under High $\mathrm{CO}_{2}$ Levels}

\author{
Adam Levi ${ }^{* *}$, Wolfgang Müller ${ }^{2,3}$ and Jonathan Erez ${ }^{1}$ \\ ${ }^{1}$ Institute of Earth Sciences, The Hebrew University of Jerusalem, Jerusalem, Israel, ${ }^{2}$ Department of Earth Sciences, Royal \\ Holloway University of London, Egham, United Kingdom, ${ }^{3}$ Institute of Geosciences, Goethe-University, Frankfurt, Germany
}

Two species of Amphistegina were cultured under four variable DIC concentrations (2340-2570 $\mu \mathrm{M})$. The variability of trace elements within the foraminiferal shells was measured in the knob area of three individuals for each DIC treatment using LAICPMS. In individuals that showed significant growth (identified via ${ }^{135} \mathrm{Ba}$-enriched seawater), $\mathrm{B}, \mathrm{Na}$, and $\mathrm{Sr}$ showed an increase with $\mathrm{DIC}$, while $\mathrm{K}$ and $\mathrm{Mg}$ were slightly lower or unchanged. Sharp transition zones between natural ${ }^{135} \mathrm{Ba}$ and the $\sim 10$-fold increased ${ }^{135} \mathrm{Ba}$ in the shells represent one quarter of a new additional chamber, which occurs roughly once a week. The shape of the transition zone is best described by a logistic equation for population growth. We propose that this reflects the dynamics of seawater vacuoles that serve the biomineralization process and provide $\mathrm{Ca}$ and DIC for calcification of Amphistegina as described in previous publications (e.g., Bentov et al., 2009). LA-ICPMS profiles in the central knob ( 70 $\mu \mathrm{m}$ depth) also revealed previously described cyclical changes in concentration of $\mathrm{Mg}$, each apparently representing a growth of a new chamber. Additional elements such as $\mathrm{K}, \mathrm{Na}$ and $\mathrm{U}$ showed similar cycles with the same frequency and phase as the $\mathrm{Mg}$ cycles. $\mathrm{Sr}$ showed variability with similar frequency but not in-phase to those of the Mg. These multi-element cycles were found both in the newly grown calcite (elevated- ${ }^{135} \mathrm{Ba}$ ) and in the natural skeleton regardless of the DIC treatments. These high $\mathrm{Mg}$ and multielement cycles seem to be an essential part of the calcification process. They may originate from the interaction with the organic matrix resulting in elevated $\mathrm{Mg}$ and other elements in primary calcite while secondary calcite of the lamination process shows lower concentrations. It is also possible that primary calcite is enriched in trace elements if an Amorphous $\mathrm{CaCO}_{3}$ (ACC) or vaterite precursors are involved. In addition, Rayleigh fractionation from a semi-closed reservoir, the presence of high $\mathrm{Mg}$ in the lattice or any combination of the previous causes may explain the trace elements enrichment. Changes in the DIC did not affect the pattern of elemental cycles in these foraminifera, suggesting that this variability is inherent to the biomineralization process.

Keywords: biomineralization, LA-ICPMS, foraminifera, Amphistegina, trace elements, Mg banding, DIC, primary calcite 


\section{INTRODUCTION}

Foraminifera shells are well-known archives for paleoceanography and paleoclimate reconstructions. In addition to the use of foraminifera for biostratigraphy and paleoecology (e.g., Climap project, 1976; Crowley, 2000), stable isotopes $\left(\delta^{18} \mathrm{O}\right.$ and $\left.\delta^{13} \mathrm{C}\right)$, trace elements and their isotopes $(\mathrm{Cd} / \mathrm{Ca}$, $\mathrm{Mg} / \mathrm{Ca}, \mathrm{U} / \mathrm{Ca}, \delta^{11} \mathrm{~B}$, and more) are successfully used for studying past ocean chemistry and paleocirculation (e.g., Emiliani and Shackleton, 1974; Sanyal et al., 1996; Lea, 1999; Nürnberg, 2000; Barker and Elderfield, 2002; Lear et al., 2002; Katz et al., 2010; Allen et al., 2016; Foster and Rae, 2016). Recently it has been proposed that $\mathrm{Na} / \mathrm{Ca}$ could be used to reconstruct past ocean calcium concentrations (Hauzer et al., 2018). However, different species of foraminifera at the same location show different shell chemistries and isotopic compositions, which are attributed to "vital effects" representing deviations from expected thermodynamic equilibrium (e.g., Erez, 1978). These deviations are mostly associated with the calcification process that is biologically controlled and thus may affect the incorporation of trace and minor elements and their isotopes into the calcite shells (e.g., Erez, 1978, 2003; Elderfield et al., 1996; Bentov and Erez, 2006; Zeebe et al., 2008; de Nooijer et al., 2014; Gussone et al., 2016). One of the main factors that control foraminiferal calcification is the carbonate system in seawater (e.g., ter Kuile et al., 1989; Spero et al., 1997; Erez, 2003). It is therefore expected that the increase in atmospheric $\mathrm{CO}_{2}\left(\mathrm{pCO}_{2}\right)$, causing ocean acidification, may reduce foraminiferal calcification as well as affect their shell chemistry (e.g., Erez, 2003; Kuroyanagi et al., 2009; Dias et al., 2010; Fujita et al., 2011; Vogel and Uthicke,
2012; McIntyre-Wressnig et al., 2013). For example $\mathrm{Mg} / \mathrm{Ca}$ in planktic foraminifera shows species-specific sensitivity to the carbonate system (e.g., Russell et al., 2004; Kisakürek et al., 2008; Allen et al., 2016; Evans et al., 2016, 2018; Holland et al., 2017; Gray and Evans, 2019).

An additional complication in the study of foraminiferal proxies is the intra-shell compositional variability (or banding) within individual specimens of both planktic and benthic foraminifera. This has been demonstrated in both trace elements and stable isotopes (e.g., Erez, 2003; Eggins et al., 2004; RollionBard et al., 2008; Hathorne et al., 2009; Branson et al., 2015; Spero et al., 2015; Jonkers et al., 2016; Fehrenbacher et al., 2017; van Dijk et al., 2017a, 2019; Geerken et al., 2019; Davis et al., 2020). Intensive experimental work (Eggins et al., 2004; Spero et al., 2015; Jonkers et al., 2016; Fehrenbacher et al., 2017) on planktic foraminifera demonstrated that Mg-rich bands are deposited during the night hours while low-Mg bands are precipitated during the daytime, perhaps connected with mitochondrial activity. Erez (2003) proposed that in large benthic foraminifera banding occurs when a new chamber is created in a two-step process: the first layer of organic-rich matrix (primary calcite) is associated with high concentrations of trace elements, while the secondary thick layer, often termed lamination, covers the existing exposed chambers and is composed of low trace element calcite (secondary calcite). The alteration between high and low elemental bands may thus be attributed to the process of sequential chamber formation (Erez, 2003; Bentov and Erez, 2005, 2006). While this may explain the daily banding in planktic foraminifera that add a chamber every day, the banding

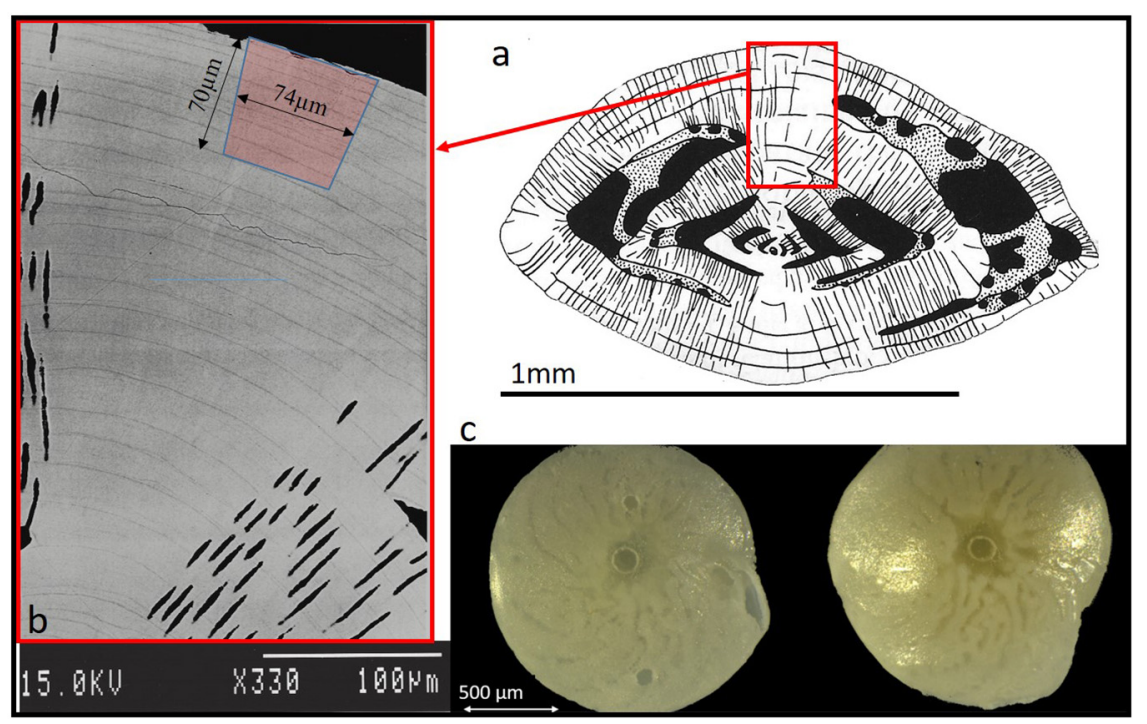

FIGURE 1 | (a) Schematic diagram of Amphistegina lobifera vertical cross section (Adapted from Reiss and Hottinger, 1984). The knob is an imperforated structure build like multi layers concentric dome. (b) Back scatter SEM image of a polished vertical section through the knob of $A$. lobifera (see Erez, 2003), note the thin dark layers representing weekly chamber growth lines. These dark layers are rich in $\mathrm{Mg}$ and $\mathrm{K}$ as well as other trace elements (see Figs below). The laser drilling marked in red is roughly $70 \mathrm{~mm}$ deep. (c) Images of the actual ablation hole in the knob of $A$. lessonii (left) and $A$. lobifera (right). 


\section{A. Lessonii ${ }^{135} \mathrm{Ba}$ to $\mathrm{Ca}$ and Logistic fitting}
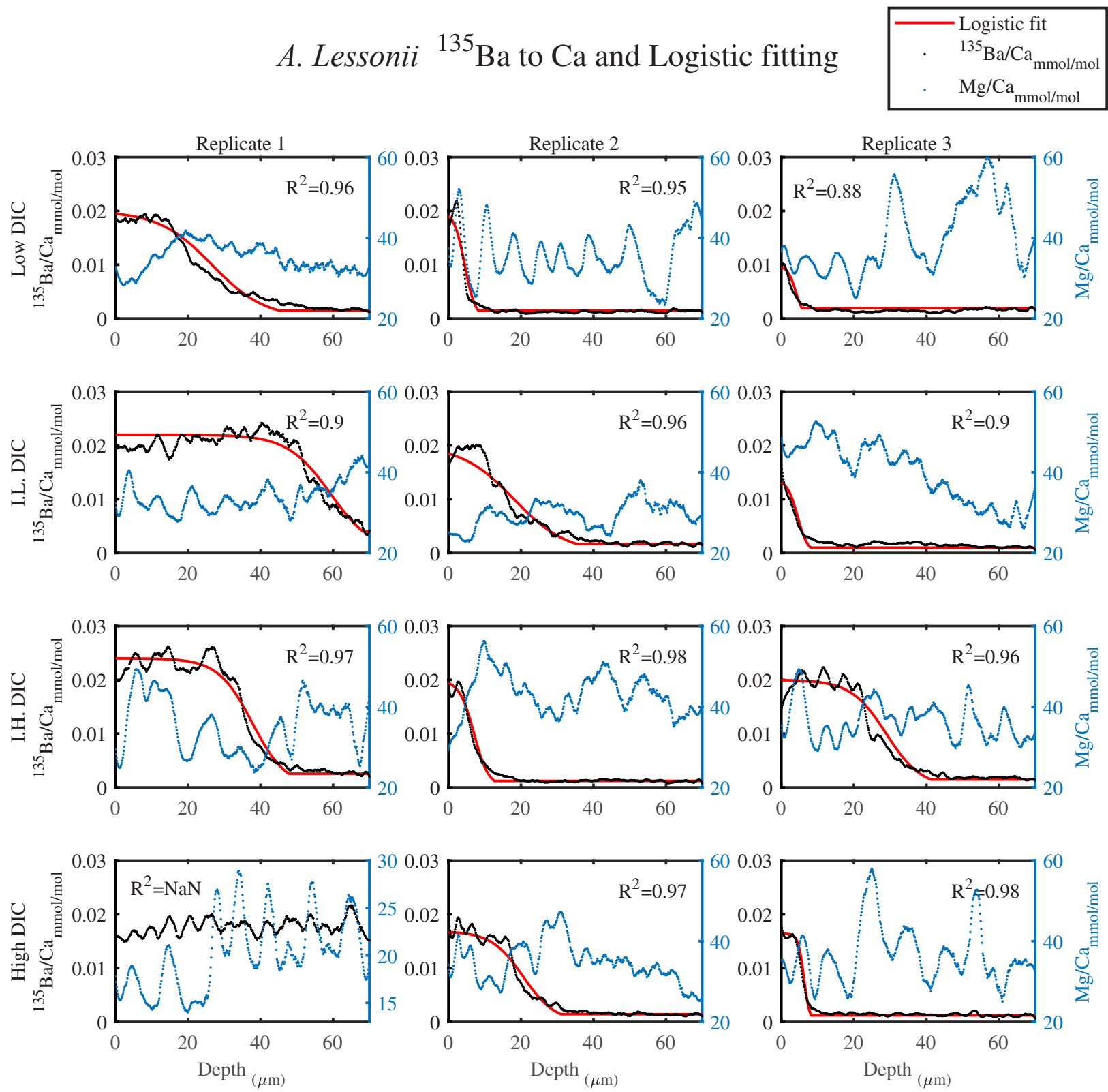

FIGURE 2 | The transition zone of ${ }^{135} \mathrm{Ba} / \mathrm{Ca}$ from natural to experimental calcite as obtained from LA-ICPMS in the knob area of $A$. lessonii (dotted black). A logistic population function was fitted to the data (red solid line). The correlation coefficients of the fitted lines are very high ( $\left.R^{2}>0.9\right)$. The dotted blue line is the Mg/Ca ratio and the high peaks represent new chambers growth. Note that there is no correlation between the newly grown calcite (high ${ }^{135} \mathrm{Ba}$ ) and the experimental $\mathrm{DIC}$ conditions. Replicates L3 and IL3 stopped growing in the middle of the transition zone and replicate H1 shows only new growth.

phenomena overall are not well-understood. Furthermore, the effect of ocean acidification on the element banding is not known.

In this study, we measured the intra-shell variability of trace elements ( $\mathrm{B}, \mathrm{Mg}, \mathrm{Na}, \mathrm{K}, \mathrm{Sr}, \mathrm{Ba}$, and $\mathrm{U}$ ) in the two benthic foraminifera species Amphistegina lobifera and A. lessonii, cultured at four DIC concentrations $(2,340,2,420,2,440$, and $2,570 \mu \mathrm{M})$. These correspond to four $\mathrm{pCO}_{2}$ levels of 430, 560, 740 , and 1,390 $\mu \mathrm{atm}$. These two species are commonly found in coral-reef environments of the Gulf of Eilat, and as such they are an important component of the carbonate sediments in this marine environment (Reiss and Hottinger, 1984). 


\section{A. Lobifera ${ }^{135} \mathrm{Ba}$ to $\mathrm{Ca}$ and Logistic fitting}
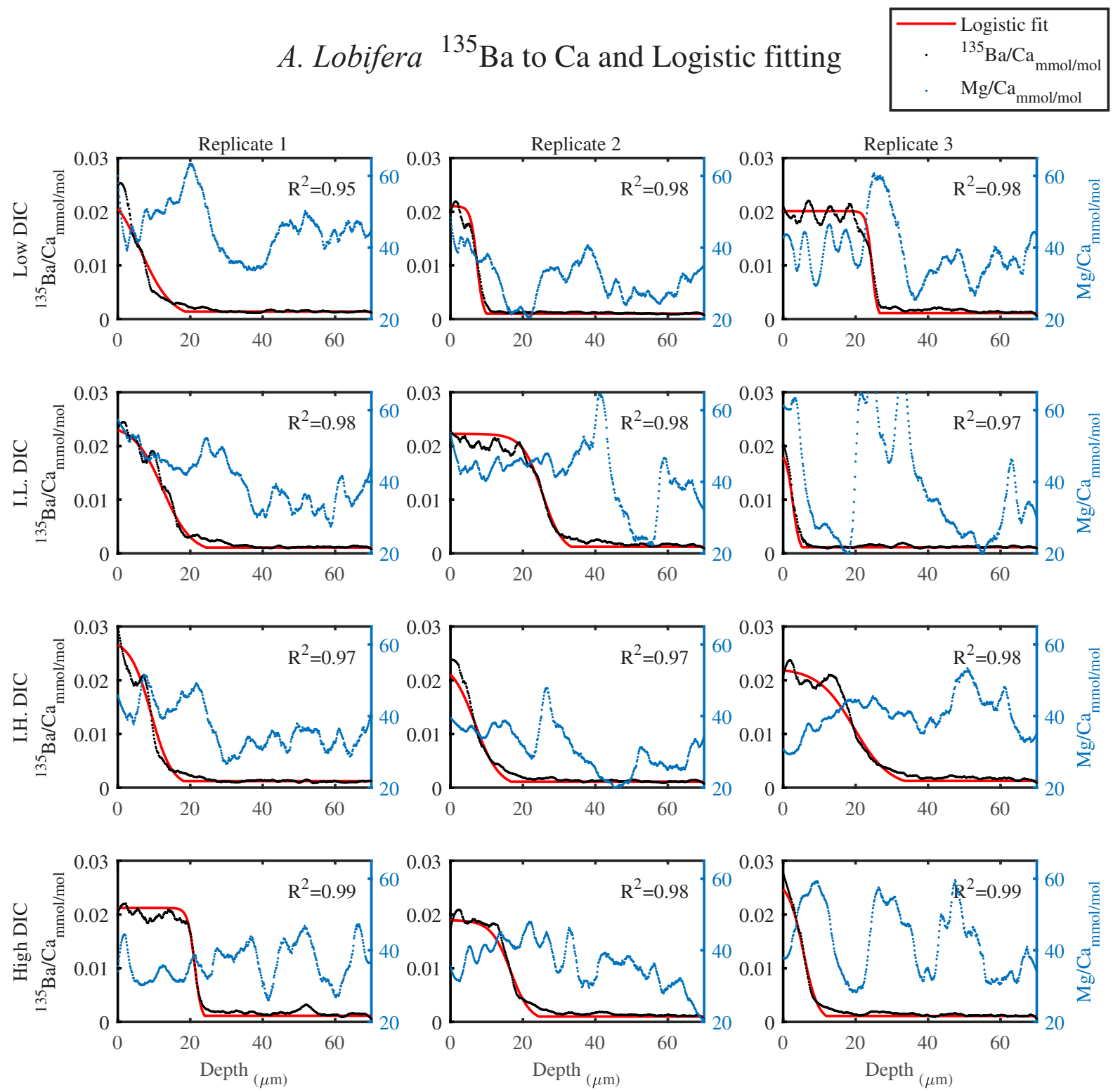

FIGURE 3 | The transition zone of ${ }^{135} \mathrm{Ba} / \mathrm{Ca}$ from natural to experimental calcite as obtained from LA-ICPMS in the knob area of $A$. Iobifera (dotted black). A logistic function was fitted to the data (red solid line). The correlation coefficients of the fitted lines are very high $\left(R^{2}>0.9\right)$. The dotted blue line is the Mg/Ca ratios and the high peaks represent new chambers growth. Note that there is no correlation between the newly grown calcite (high $\left.{ }^{135} \mathrm{Ba}\right)$ and the experimental $\mathrm{DIC}$ conditions.

\section{MATERIALS AND METHODS}

Two sediment-producing benthic foraminifera A. lobifera and A. lessonii were selected for this study. These two species are common in the Gulf of Eilat, and are an important component in carbonate sediment in this marine environment (Erez, 2003) particularly in the area of the coral reef. Both species produce high-Mg calcite shells at approximately 3-4 mol\% $\mathrm{MgCO}_{3}$ (Erez, 2003). The foraminifera were collected from stones covered with turf algae in the Gulf of Eilat (Aqaba) at 3-5 m water depth. They were sieved and the 400-600 $\mu \mathrm{m}$ fraction of approximately 1400 live individuals of each species was used for the experiment.
Initially the foraminifera were cultured in seawater with Calcein dye (Sigma-Aldrich, $40 \mu \mathrm{M} / \mathrm{L}$ ) for 3 days and then washed with seawater (Eilat seawater) and divided to six groups (four experimental groups and two control groups). Both species were cultured in seawater sealed $120 \mathrm{ml}$ Erlenmeyer flasks in four different DIC treatments. During the experiment (14 weeks) the Erlenmeyer flasks were kept at constant temperature of $25^{\circ} \mathrm{C}$ and light intensity of $60 \mu \mathrm{mol}$ photons $\mathrm{m}^{-2} \mathrm{~s}^{-1}$, with a diurnal cycle of $12 \mathrm{~h}$ light. Once a week water was exchanged and sampled for oxygen, DIC, alkalinity, and $\mathrm{pH}$ measurements (methods and results will be reported in a separate publication). The salinity was constant at $40.6 \%$, the normal salinity of Eilat seawater. 

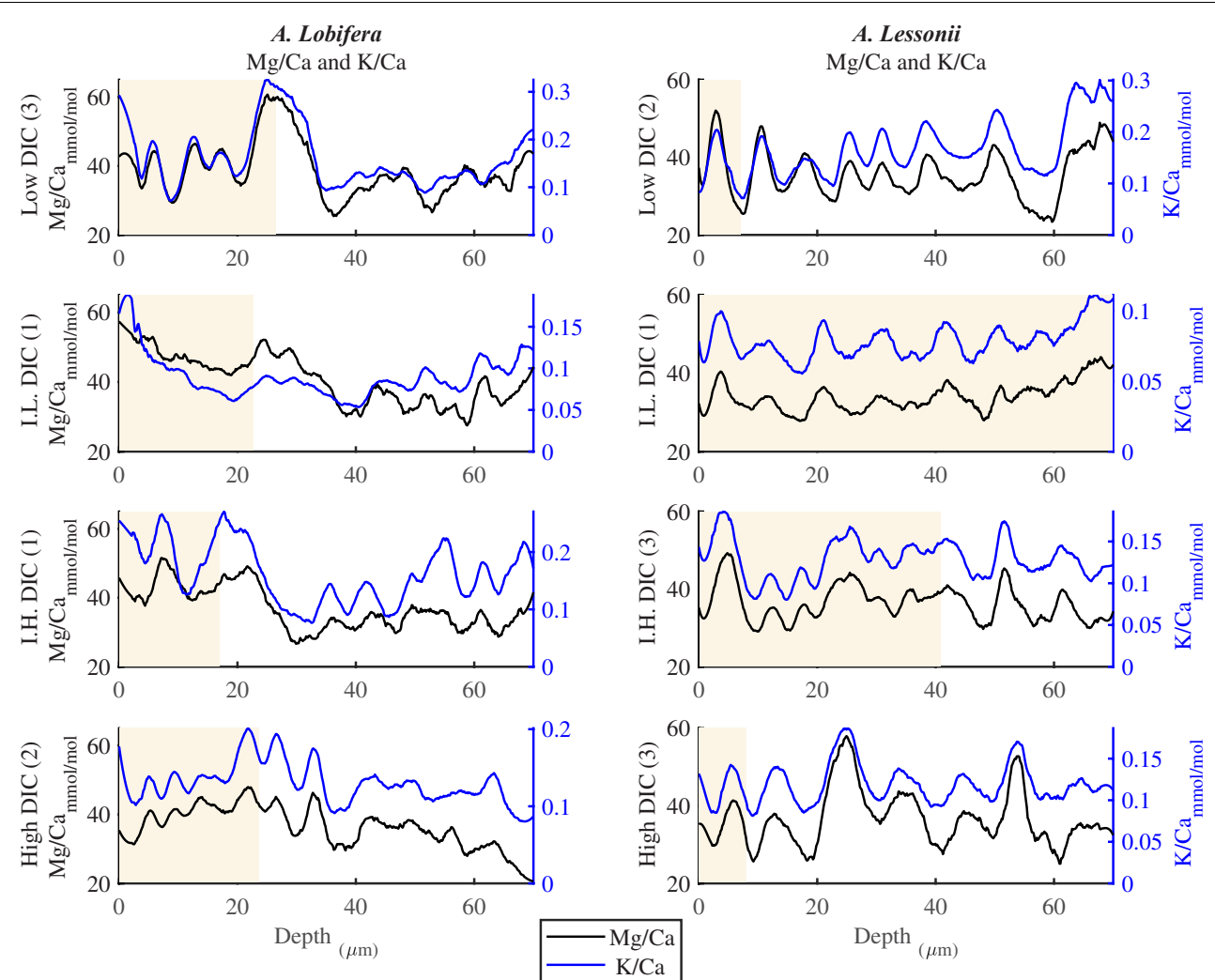

FIGURE 4 | K/Ca and Mg/Ca ratios in the knob profile of $A$. lessonii and A. lobifera for one selected specimen from each DIC treatment (data for all the specimens are given in the Supplementary Material). Note that the $\mathrm{K}$ bands is following the $\mathrm{Mg}$ ones with high fidelity in both frequency and amplitude. These high $\mathrm{Mg}-\mathrm{K}$ bands represent the dark layers shown in Fig $1 \mathrm{~b}$ and are associated with the organic rich primary calcite while the thick low Mg-K bands represent the secondary calcite of the lamination process. The DIC treatment did not affect the elemental cycles.

\section{Water Preparation}

Initially 20 liters of Eilat seawater was filtered throughout a $0.22-\mu \mathrm{m}$ filter and spiked with ${ }^{135} \mathrm{Ba}$ (Oak Ridge National Laboratory, United States) to reach a concentration of factor of $\sim 10$ from seawater that unequivocally allows the identification of post-culture growth segments by LA-ICPMS (Laser Ablation Inductively Coupled Plasma Mass Spectrometry). Five liters were transferred to a $\mathrm{CO}_{2}$ bubbling system to prepare four $\mathrm{pCO}_{2}$ concentrations, 430, 560, 740, and $1390 \mathrm{ppm}$. The prepared waters were transferred to sealed bags (Supelco 30229-U) from which the actual experimental water were used for periodic water exchange ( $\sim$ once per week). The alkalinity, $\mathrm{pH}$, oxygen and DIC of the reservoirs were measured four times during the experiment. During the experiment, the DIC in the sealed reservoirs increased in all bags (in part due to microbial oxidation of DOM with oxygen depletion). The alkalinity values remained constant and averaged $2411 \pm 17 \mu \mathrm{mol} \mathrm{kg}^{-1}$ while the $\mathrm{pH}$ decreased. The exact values and their effect on the physiology (photosynthesis, calcification and respiration) of these foraminifera will be described elsewhere. The average DIC valued for the whole experiment are $2340 \mu \mathrm{mol}$ (low DIC marked as L), $2420 \mu \mathrm{mol}$ (intermediate low, IL), $2440 \mu \mathrm{mol}$ (intermediate high, IH) and $2570 \mu \mathrm{mol}$ (high, H). Here we report mainly on the shell chemistry recorded in the knob area of these foraminifera.

\section{Sample Preparation and Analysis}

At the end of the experiments, the cleaning process was done in two phases. The foraminifera from each treatment were washed five times with distilled water and dried in the oven $\left(50^{\circ} \mathrm{C}\right.$, $24 \mathrm{~h}$ ) then counted, weighted (total weight) and transferred to the organic matter cleaning procedure, by soaking the specimens in sodium hypochlorite (Sigma-Aldrich, 1:10) overnight while shaking gently. Specimens were washed five times again in distilled water, dried, and weighed again (shell weight).

\section{LA-ICPMS}

From each treatment, three foraminifers of each species were selected for laser ablation ICPMS analyses. We selected specimens of approximately equal shell size and close to the mean size of each treatment in order to limit the size dependency of the shell chemistry (Elderfield et al., 2002; Friedrich et al., 2012). In addition we examined their growth (the presence of several non-fluorescent chambers past the Calcein stain, see SI). Foraminifers were loosely fixed on top of Blu-Tak inside 1 inch stainless steel rings and analyzed using the RESOlution M-50 LA system coupled to an Agilent 8800 triple-quadrupole ICPMS at Royal Holloway University of London (Müller et al., 2009). The analytical method was optimized for the determination of trace elements via slow depth-profiling (for details see 

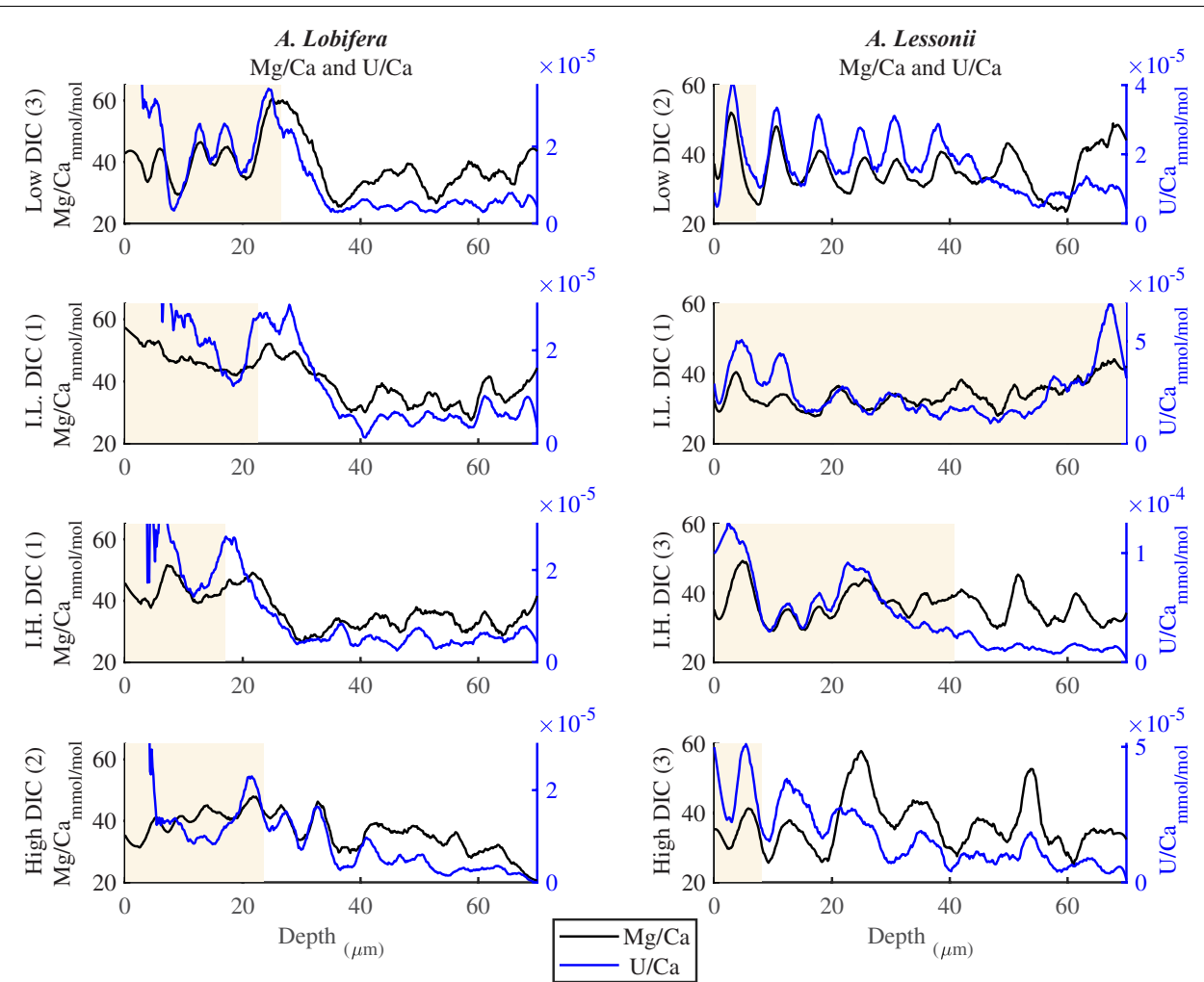

FIGURE 5 | U/Ca and Mg/Ca ratios in the knob profile of $A$. lessonii and $A$. lobifera for one selected specimen for the four DIC treatments (all the data are given in the Supplementary Material). The two elements show similar cycles in both frequency and amplitude. In that respect, this is similar to the K/Ca ratio shown in Figure 4. The DIC treatment did not affect the elemental cycles.

Griffiths et al., 2013 and Evans et al., 2015). Laser spot size of $74 \mu \mathrm{m}$ for $A$. lessonii and $96 \mu \mathrm{m}$ for A. lobifera with repetition rate of $2 \mathrm{~Hz}$ was used to ablate into the knob with an approximate vertical drill rate of $\sim 0.15 \mu \mathrm{m} /$ pulse. To improve sensitivity, $6 \mathrm{ml}$ $\min ^{-1} \mathrm{H}_{2}$ was used as an additional diatomic gas, added to $\mathrm{He}$ downstream of the LA cell. Each specimen was ablated once for $240 \mathrm{~s}$, which reached an ablation depth of $\sim 50-70 \mu \mathrm{m}$ (Figure 1).

\section{DATA ANALYSIS}

Data reduction was done with Iolite software (Paton et al., 2011), trace element DRS method (Woodhead et al., 2007) with NIST SRM 612 (Jochum et al., 2011) as external standard. Data processing performed off-line using a commercial software package (MATLAB R2017a, The MathWorks Inc., Natick, MA, 2000).

\section{RESULTS}

\section{Growth of Foraminifera}

All four groups showed a positive growth based both on weekly alkalinity depletions and on final weighing as follows: Groups L, IL, IH, H (2340, 2420, 2440, $2570 \mu \mathrm{M}$ DIC) increased their $\mathrm{CaCO}_{3}$ weight by $\sim 100, \sim 70, \sim 78$, and $\sim 30 \%$, respectively. As mentioned previously, a detailed report on the calcification and symbionts photosynthesis will be reported elsewhere. Here we concentrate on the variability of the internal shell chemistry as observed mainly with the LA-ICPMS.

As shown in Figure 1, LA profiles with high vertical resolution of $0.15 \mathrm{~mm}$ in the solid $\mathrm{CaCO}_{3}$ of the knob area were performed. ${ }^{135} \mathrm{Ba} / \mathrm{Ca}$ ratios in the knob of $A$. lobifera and in A. lessonii were used as a chemical marker for the start of new shell deposition during the experiment (Figures 2, 3). The transition zone is very clear for most of the specimens and reach a final ${ }^{135} \mathrm{Ba} / \mathrm{Ca}$ value of $\sim 0.2 \mu \mathrm{mol} / \mathrm{mol}$ that is similar in both A. lobifera and A. lessonii. This value is roughly 10 times higher than the natural ratio for this isotope. The transition zone is $\sim 15-20 \mu \mathrm{m}$ wide in A. lessonii and $\sim 5-10 \mu \mathrm{m}$ in A. lobifera. The new skeleton thickness shows large variability between individuals of the same treatment (i.e,. DIC values) that mask to a large extent the variability between the treatments (see further details in the section "Discussion").

Based on the identity of the newly grown shell we describe below the elemental cycles within the knob and the overall average ratios of several elements in the new and the natural shell.

\section{Element to Ca Variability in the Knob Profiles at Different DIC}

For all the specimens we observe the previously described high and low Mg bands in the knob area (Erez, 2003). Most of 

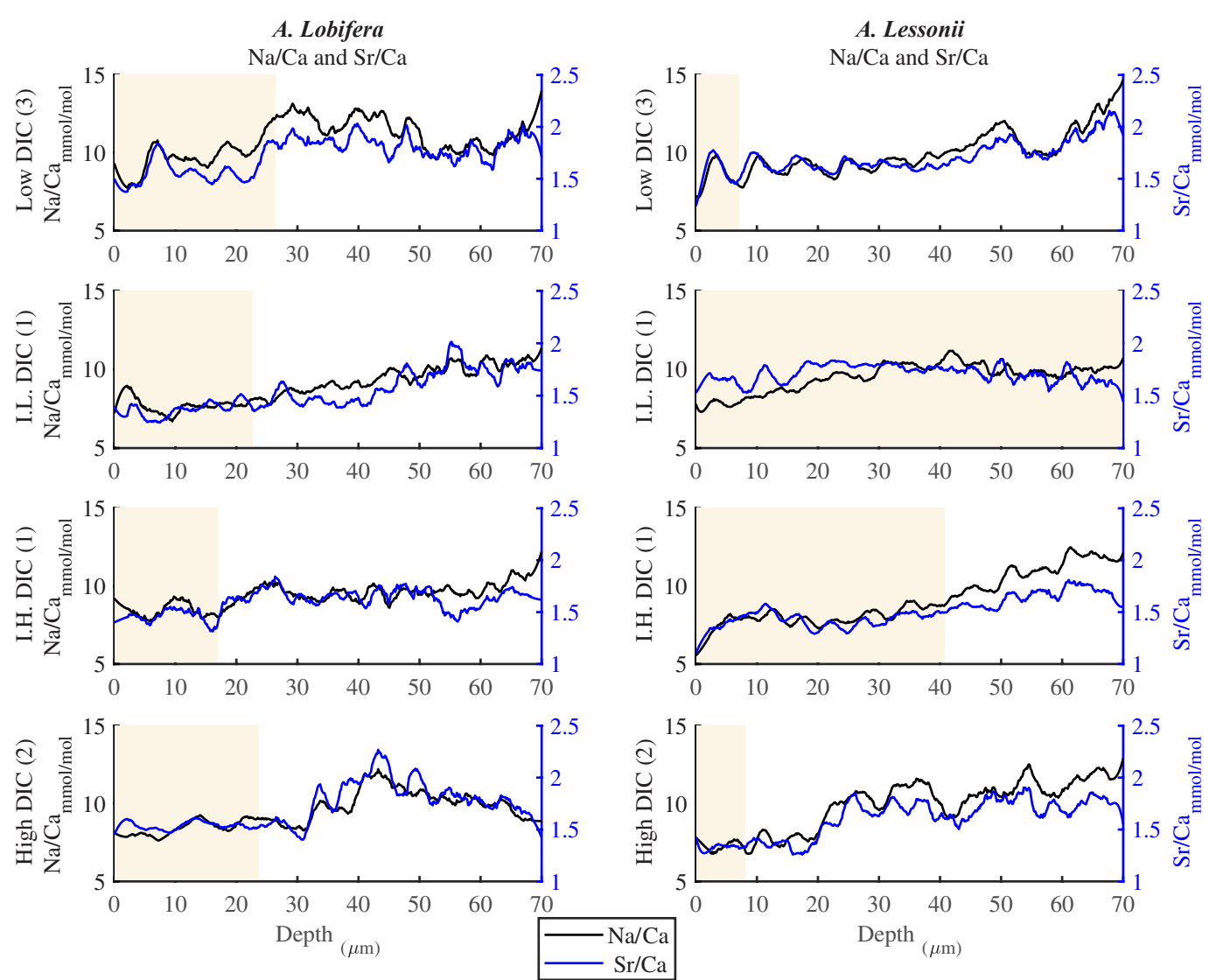

FIGURE 6 | Na/Ca and Sr/Ca ratios in the knob profile of $A$. lessonii and $A$. lobifera for one selected specimen for each DIC treatments (all the data are given in the Supplementary Material). It should be noted that these two elements show less similarity to the Mg-K-U cycles shown in Figures $\mathbf{4}$, $\mathbf{5}$. On the whole, however, the number of cycles (i.e., the frequency) is similar to the those of $\mathrm{Mg}$. The DIC treatment did not affect the elemental cycles.

the profiles $(\sim 70 \mu \mathrm{m}$ in length) comprise $7-8$ bands of $\mathrm{Mg}$ rich layers that equals to $60-70 \%$ of the last growth circular whorl that contain $\sim 11-12$ chambers in these organisms. Every high-Mg band represents a new chamber and is followed by a low-Mg band (Figures 4, 5). There is no apparent changes in the $\mathrm{Mg}$ banding (frequency and phase) as a function of the DIC treatment for both species, i.e., the newly precipitated cycles show continuation of the natural cycles. Here again the variability within treatment as large as the variability between DIC treatments (Figures 4, 5). A. lobifera showed Mg/Ca range of $20-75 \mathrm{mmol} / \mathrm{mol}$, and $A$. lessoni shows lower range of 14 to $60 \mathrm{mmol} / \mathrm{mol}$. The $\mathrm{Mg} / \mathrm{Ca}$ cycles were used as a template for comparison to the other elements. The K/Ca cycles throughout the knob are similar to those of the $\mathrm{Mg} / \mathrm{Ca}$, both frequency and phase regardless of the DIC treatment (Figure 4). The K/Ca values ranged from 0.45 to $0.35 \mathrm{mmol} / \mathrm{mol}$ in $A$. lobifera and 0.3 to $0.42 \mathrm{mmol} / \mathrm{mol}$ in $A$. lessoni. The $\mathrm{Na} / \mathrm{Ca}$ (Figure 5) varied from 7 to 14 in $A$. lobifera and from 6 to $14 \mathrm{mmol} / \mathrm{mol}$ in A. lessoni showing a decrease from the old shell (high values) to the new part of the shell (low values), the cycles however, are similar to the $\mathrm{Mg} / \mathrm{Ca}$ regardless of the DIC treatment. $\mathrm{Sr} / \mathrm{Ca}$ show the same trend of decreasing values from 1.2 to $2.1 \mathrm{mmol} / \mathrm{mol}$ and 1.25 to $2.4 \mathrm{mmol} / \mathrm{mol}$, respectively. The
$\mathrm{Sr} / \mathrm{Ca}$ show the same number of cycles of the $\mathrm{Mg} / \mathrm{Ca}$ but with a phase shift of $\sim 1 / 4$ cycle (Figure 6). The U/Ca cycles are very similar to those of the $\mathrm{Mg}$ both in frequency and in phase, but has a general trend of increase in the new shell in all treatments (Figure 5).

\section{Average Changes in Shell Composition at Different DIC}

The average element to Ca ratios between the newly grown shell and the original natural shell are given in Table $\mathbf{1}$ and Figure 7 (A. lobifera) and 8 (A. lessoni). Significant differences between the new and natural shells were tested using Two Sample $t$-test (Table 2). Error bars in Figures 7, 8 represent \pm the average standard deviation for the new and natural parts of the shell for each experimental DIC.

$\mathrm{B} / \mathrm{Ca}, \mathrm{Na} / \mathrm{Ca}$ and $\mathrm{Sr} / \mathrm{Ca}$ in the new shell of $A$. lobifera are significantly lower than the natural shell. For $\mathrm{Mg} / \mathrm{Ca}$ and $\mathrm{K} / \mathrm{Ca}$ the new shells show ratios that are significantly higher than the natural shell (Figure 7 and Tables 1, 2). For A. lessoni $\mathrm{B} / \mathrm{Ca}$, $\mathrm{Na} / \mathrm{Ca}$ and $\mathrm{Sr} / \mathrm{Ca}$ in the new shell ratios are significantly lower than the natural shell. The $\mathrm{Mg} / \mathrm{Ca}$ and $\mathrm{K} / \mathrm{Ca}$ of the new shells show ratios that are variable, slightly lower or similar to the 
TABLE 1 | Element to Ca ratios in the new shell precipitated under the experimental conditions and the natural original shell (Figures 7, 8).

\begin{tabular}{|c|c|c|c|c|c|c|c|c|c|c|c|c|c|c|}
\hline \multirow[t]{2}{*}{ DIC $(\mu \mathrm{M})$} & \multirow{2}{*}{$\begin{array}{l}\text { Part of the shell } \\
\text { No. of LA shots }\end{array}$} & \multirow[t]{2}{*}{ Average type } & \multicolumn{2}{|c|}{$\mathrm{B} / \mathrm{Ca}$} & \multicolumn{2}{|c|}{$\mathrm{Na} / \mathrm{Ca}$} & \multicolumn{2}{|c|}{$\mathrm{Mg} / \mathrm{Ca}$} & \multicolumn{2}{|c|}{$\mathrm{K} / \mathrm{Ca}$} & \multicolumn{2}{|c|}{$\mathrm{Sr} / \mathrm{Ca}$} & \multicolumn{2}{|c|}{${ }^{135} \mathrm{Ba} / \mathrm{Ca}$} \\
\hline & & & $\mathrm{mmol} / \mathrm{mol}$ & sd & $\mathrm{mmol} / \mathrm{mol}$ & sd & $\mathrm{mmol} / \mathrm{mol}$ & sd & $\mathrm{mmol} / \mathrm{mol} 1$ & sd & $\mathrm{mmol} / \mathrm{mol}$ & sd & $\mathrm{mmol} / \mathrm{mol}$ & sd \\
\hline \multicolumn{15}{|c|}{ Amphistegina lessonii new and natural shell element to calcium ratio } \\
\hline \multirow[t]{4}{*}{2340} & New & Normal & 0.09 & 0.02 & 7.99 & 0.64 & 37.73 & 3.42 & 0.17 & 0.02 & 1.49 & 0.09 & 1.3E-02 & 4.0E-03 \\
\hline & 267 & Weighted & 0.11 & 0.03 & 8.10 & 0.47 & 36.67 & 2.82 & 0.17 & 0.01 & 1.49 & 0.06 & 1.4E-02 & $3.1 \mathrm{E}-03$ \\
\hline & Natural & Normal & 0.56 & 0.17 & 12.37 & 0.71 & 37.95 & 4.02 & 0.28 & 0.05 & 1.81 & 0.13 & 2.2E-03 & 8.6E-04 \\
\hline & 1064 & Weighted & 0.59 & 0.22 & 12.63 & 0.70 & 38.68 & 5.06 & 0.29 & 0.05 & 1.82 & 0.18 & $1.9 \mathrm{E}-03$ & 8.3E-04 \\
\hline \multirow[t]{4}{*}{2420} & New & Normal & 0.08 & 0.01 & 8.97 & 0.45 & 35.18 & 7.56 & 0.18 & 0.10 & 1.58 & 0.13 & $1.5 \mathrm{E}-02$ & 4.1E-03 \\
\hline & 600 & Weighted & 0.08 & 0.01 & 9.29 & 0.33 & 32.32 & 4.94 & 0.11 & 0.07 & 1.68 & 0.10 & $1.8 \mathrm{E}-02$ & $3.4 \mathrm{E}-03$ \\
\hline & Natural & Normal & 0.22 & 0.11 & 10.33 & 0.63 & 31.33 & 1.98 & 0.14 & 0.05 & 1.67 & 0.07 & $6.9 \mathrm{E}-03$ & 7.7B-03 \\
\hline & 693 & Weighted & 0.31 & 0.08 & 10.57 & 0.50 & 29.95 & 0.75 & 0.17 & 0.02 & 1.63 & 0.10 & 1.7E-03 & $2.8 \mathrm{E}-03$ \\
\hline \multirow[t]{4}{*}{2440} & New & Normal & 0.08 & 0.02 & 8.10 & 1 & 36.82 & 1.40 & 0.16 & 0.04 & 1.49 & 0.17 & 1.8E-02 & 2.7E-03 \\
\hline & 543 & Weighted & 0.09 & 0.01 & 8.54 & 1.16 & 36.17 & 1.56 & 0.14 & 0.03 & 1.56 & 0.21 & 1.9E-02 & 3.1E-03 \\
\hline & Natural & Normal & 0.40 & 0.19 & 10.62 & 0.46 & 36.35 & 2.23 & 0.14 & 0.01 & 1.70 & 0.08 & 4.3E-03 & $3.5 \mathrm{E}-03$ \\
\hline & 765 & Weighted & 0.44 & 0.20 & 10.80 & 0.60 & 37.28 & 2.77 & 0.14 & 0.02 & 1.71 & 0.09 & 3.2E-03 & $3.8 \mathrm{E}-03$ \\
\hline \multirow[t]{6}{*}{2570} & New & Normal & 0.07 & 0 & 7.62 & 0.58 & 29.81 & 6.87 & 0.09 & 0.02 & 1.41 & 0.10 & 1.5E-02 & 1.6E-03 \\
\hline & 695 & Weighted & 0.07 & 0.01 & 8.08 & 0.70 & 24.23 & 7.95 & 0.07 & 0.02 & 1.49 & 0.12 & 1.7E-02 & $1.8 \mathrm{E}-03$ \\
\hline & Natural & Normal & 0.36 & 0.24 & 10.28 & 1.41 & 28.72 & 6.12 & 0.08 & 0.03 & 1.68 & 0.10 & $6.8 \mathrm{E}-03$ & 7.7E-03 \\
\hline & 712 & Weighted & 0.55 & 0.19 & 11.35 & 0.81 & 33.19 & 1.10 & 0.10 & 0.02 & 1.75 & 0.02 & 1.3E-03 & 7.7E-04 \\
\hline & 2105 & Total new & 0.08 & 0.01 & 8.33 & 0.67 & 33.62 & 4.56 & 0.14 & 0.04 & 1.52 & 0.12 & 1.6E-02 & 3.0E-03 \\
\hline & 3234 & Total natural & 0.43 & 0.18 & 11.12 & 0.73 & 34.18 & 3.01 & 0.17 & 0.03 & 1.72 & 0.10 & 3.5E-03 & 3.5E-03 \\
\hline \multicolumn{15}{|c|}{ Amphistegina lobifera new and natural shell element to calcium ratio } \\
\hline \multirow[t]{4}{*}{2340} & New & Normal & 0.09 & 0.02 & 8.26 & 0.99 & 42.13 & 2.10 & 0.19 & 0.01 & 1.43 & 0.09 & 1.9E-02 & 8.4E-04 \\
\hline & 267 & Weighted & 0.10 & 0.02 & 8.88 & 1.22 & 41.20 & 2.07 & 0.18 & 0.02 & 1.48 & 0.11 & $1.9 \mathrm{E}-02$ & 7.4E-04 \\
\hline & Natural & Normal & 0.39 & 0.09 & 11.76 & 1.27 & 37.21 & 5.90 & 0.18 & 0.04 & 1.75 & 0.17 & 1.3E-03 & 2.0E-04 \\
\hline & 1093 & Weighted & 0.39 & 0.11 & 11.74 & 1.57 & 36.92 & 7.43 & 0.18 & 0.04 & 1.73 & 0.22 & 1.3E-03 & 2.5E-04 \\
\hline \multirow[t]{4}{*}{2420} & New & Normal & 0.13 & 0.03 & 8.48 & 0.57 & 51.94 & 6.57 & 0.19 & 0.12 & 1.39 & 0.06 & 1.9E-02 & $1.3 \mathrm{E}-03$ \\
\hline & 282 & Weighted & 0.11 & 0.02 & 8.45 & 0.62 & 47.50 & 5.23 & 0.12 & 0.08 & 1.42 & 0.08 & $1.9 \mathrm{E}-02$ & 8.3E-04 \\
\hline & Natural & Normal & 0.30 & 0.11 & 10.83 & 0.50 & 35.19 & 2.75 & 0.09 & 0.02 & 1.87 & 0.08 & 1.4E-03 & 2.6E-04 \\
\hline & 1038 & Weighted & 0.27 & 0.15 & 10.82 & 0.57 & 34.56 & 3.29 & 0.09 & 0.02 & 1.87 & 0.10 & 1.3E-03 & 2.9E-04 \\
\hline \multirow[t]{4}{*}{2440} & New & Normal & 0.07 & 0.01 & 8.09 & 0.29 & 39.30 & 3.22 & 0.19 & 0.05 & 1.47 & 0.06 & 2.0E-02 & 8.5E-04 \\
\hline & 245 & Weighted & 0.07 & 0.01 & 8.15 & 0.28 & 38.75 & 3.68 & 0.17 & 0.06 & 1.50 & 0.08 & 2.0E-02 & $1.0 \mathrm{E}-03$ \\
\hline & Natural & Normal & 0.21 & 0.11 & 9.98 & 0.30 & 34.54 & 5.60 & 0.14 & 0.04 & 1.72 & 0.10 & 1.3E-D3 & 3.0E-04 \\
\hline & 1000 & Weighted & 0.22 & 0.14 & 9.94 & 0.36 & 33.70 & 6.54 & 0.14 & 0.05 & 1.72 & 0.12 & 1.3E-03 & 3.4E-04 \\
\hline \multirow[t]{6}{*}{2570} & New & Normal & 0.07 & 0 & 8.68 & 0.53 & 39.12 & 4.18 & 0.10 & 0.03 & 1.54 & 0.09 & 2.0E-02 & $1.5 \mathrm{E}-03$ \\
\hline & 303 & Weighted & 0.07 & 0 & 8.86 & 0.70 & 37.22 & 4.26 & 0.09 & 0.04 & 1.58 & 0.09 & 1.9E-02 & $1.4 \mathrm{E}-03$ \\
\hline & Natural & Normal & 0.37 & 0.10 & 10.77 & 0.52 & 34.53 & 2.69 & 0.11 & 0.01 & 1.84 & 0.06 & 1.3E-03 & 2.4E-04 \\
\hline & 1057 & Weighted & 0.36 & 0.12 & 10.77 & 0.61 & 34.50 & 3.17 & 0.11 & 0.01 & 1.85 & 0.08 & 1.3E-03 & 2.9E-04 \\
\hline & 1097 & Total new & 0.09 & 0.01 & 8.48 & 0.65 & 42.14 & 3.91 & 0.15 & 0.05 & 1.48 & 0.08 & 1.9E-02 & $1.1 \mathrm{E}-03$ \\
\hline & 4188 & Total natural & 0.32 & 0.12 & 10.83 & 0.71 & 35.14 & 4.67 & 0.13 & 0.03 & 1.79 & 0.12 & 1.3E-03 & 2.7E-04 \\
\hline
\end{tabular}

We compare the average and the standard deviation (sd) of three individuals for each treatment, with the weighted average and sd based on the individual LA shots for each individual. As can be seen for all elemental ratios the values of the two calculations are very similar and are within the sd of the two types of averages. 

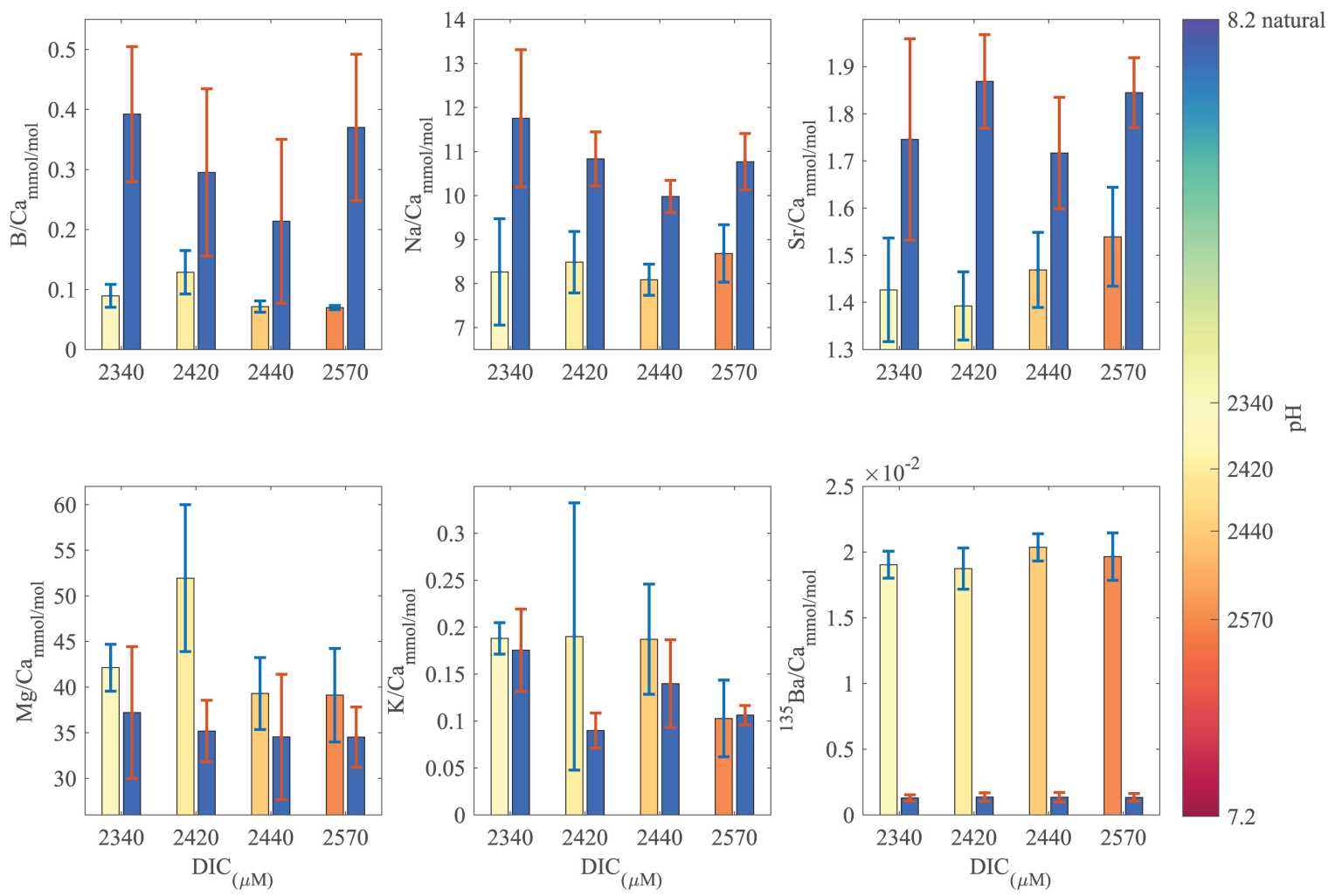

FIGURE 7| Averages of El/Ca ratios of the natural-original shells of Amphistegina lobifera in comparison with the newly grown shell under the DIC modified experimental conditions. For $\mathrm{B} / \mathrm{Ca}, \mathrm{Na} / \mathrm{Ca}$ and $\mathrm{Sr} / \mathrm{Ca}$ the new shell ratios are significantly lower than the original shell. For $\mathrm{K} / \mathrm{Ca}$ and $\mathrm{Mg} / \mathrm{Ca}$ the new shells show ratios that are significantly higher than the original shell (see Tables 1, 2 for statistics). ${ }^{135} \mathrm{Ba} / \mathrm{Ca}$ show the enrichment of the ${ }^{135} \mathrm{Ba}$ that was added to the culture media to mark the newly precipitated calcite. The numbers on the colored $\mathrm{pH}$ bar represent the experimental average DIC measurements during the experiments.

natural shell (Figure 8 and Tables 1, 2) thus not affected by the DIC increase.

\section{DISCUSSION}

\section{Transition Zone Dynamics}

The increase of the ${ }^{135} \mathrm{Ba}$ in the newly precipitated shell due to the spike in the experimental medium, give a marker for the start of the new growing phase. The part of the increase in the ${ }^{135} \mathrm{Ba}$ concentration to a steady state value (i.e., transition zone) can be used to understand the calcification mechanism. The transition shape is rather uniform and can be fitted with a logistic equation (Verhulst, 1938) that investigates a standard model of population growth in a constrained environment.

$$
P_{(t)}=\frac{K}{1+\left(\frac{K-P_{0}}{P_{0}}\right) e^{-r t}}
$$

In the case $\mathrm{P}$ is the ${ }^{135} \mathrm{Ba}$ concentration at given time, " $K$ " is the maximum concentration of the ${ }^{135} \mathrm{Ba}(\sim 0.2 \mu \mathrm{M})$, " $P_{0}$ " is the concentration at time zero, " $r$ " is the rate constant and " $t$ " is time (or depth). This equation represents biological population growth, which approaches a steady state " $K$ " (Table 3 ). The application of this formulation can be justified if we think about the population of the seawater vacuoles that supply the ${ }^{135} \mathrm{Ba}$ to the calcification site. The first vacuoles containing the spike dilute with the previous older vacuoles and with time the number of the new vacuoles increases (and the old vacuoles decrease) until all the vacuoles contain the Ba spike. The maximum concentration in the skeleton is determined by the distribution coefficient of $\mathrm{Ba}$ in the foraminiferal calcite.

In Figures 2, 3 (red line) we show the best fit of the logistic function to the ${ }^{135} \mathrm{Ba}$ data (black dots). The correlation coefficients are very high (all above 0.9), suggesting that the model indeed describes well the data, and this supports the seawater vacuolization mechanism proposed by Bentov et al., 2009 . In this case the " $t$ " Parameter is distance in $\mu \mathrm{m}$ between the natural ${ }^{135} \mathrm{Ba}\left(\mathrm{P}_{0}\right)$ and the equilibrium values of the spike $(K)$, obviously, this distance represents the time of saturation of the ${ }^{135} \mathrm{Ba}$ pool, which we assume is equal to the complete replacement of the old seawater vacuoles with the new ones. If we assume that $\mathrm{Ba}$ is following $\mathrm{Ca}$ during the calcification process, this indicates a very large internal Ca pool roughly equivalent to the amount of $\mathrm{Ca}$ in a new chamber (and the lamination process associated with these lamellar species). Such 
internal Ca pools were described by Erez, 2003 for A. lobifera. Such large concentration ( $\sim$ a few Molar) of $\mathrm{Ca}$ in this pool is most probably a solid phase, most likely amorphous calcium carbonate (ACC).

There is no clear relationship between the DIC treatments and the thickness of the transition zone possibly because the variability between individuals in each treatment was as large as the variability between treatments. Similarly, there was no significant correlation between the thickness of the transition zone and the new skeleton thickness or the rate constant parameter " $r$ " and the total growth (Figure 9).

\section{Trace Element in the Knob Profiles and the Role DIC}

The shell (within the knob) is composed of three parts: the natural growth (before collection) the pre experiment (short maintenance of the foraminifera before the experiment while being labeled with Calcein), and finally the part that grew during the experiment labeled with ${ }^{135} \mathrm{Ba}$.

The $\mathrm{Mg}$ banding in these species is different from that observed in the planktonic species (e.g., Eggins et al., 2003, 2004) mainly because $A$. lobifera and $A$. lessonii are involute species with a central knob (where the measurements were made) that accumulate skeleton for each new chamber (Figure 1). In addition, Ampnistegina (both species) have a long life cycle (of 6-12 months) as opposed to the short life cycle of the planktonic ones ( $\sim 30$ days or less).

The Mg in this genus (as well as in other foraminifera) show growth cycles of $\mathrm{Mg}$ rich layers that have been described before (Eggins et al., 2003; Erez, 2003; Fehrenbacher et al., 2017; Geerken et al., 2018, 2019). The Mg cycles are observed both in the natural and in the new skeleton (Figures 2, 3, blue dots), regardless of the large variations in the DIC. Surprisingly, the elevated DIC concentrations did not have a significant effect on the patterns of the intrashell variability. This is supported by Geerken et al. (2019) showing that the high and low concentration bands are not effected by salinity and temperature. On the other hand, the averages of the measured trace elements to calcium ratios in the newly calcified shells did show some changes compared to the previous natural shells that may be related to the DIC treatment (see below, Figures 7, 8 and Table 1). Unlike the previous observations on A. lobifera (Erez, 2003), the Mg banding signal from the LA-ICPMS is less regular and the peaks are less

TABLE 2 | Two sample $t$-test $P$ values (using matlab test2 function).

\begin{tabular}{|c|c|c|c|c|c|c|c|c|}
\hline Alpha $=0.025$ & $\operatorname{DIC}(\mu \mathrm{M})$ & Forams\# & B & $\mathrm{Na}$ & $\mathrm{Sr}$ & Mg & $\mathbf{K}$ & df \\
\hline \multicolumn{9}{|c|}{ Amphistegina lobifera $t$-test $P$ values - at the $97.5 \%$ significance level } \\
\hline & \multirow[t]{3}{*}{2340} & 1 & $0.0000^{-}$ & $0.0000^{-}$ & $0.0000^{-}$ & $0.9134^{\mathrm{ns}}$ & $0.0000^{-}$ & 173 \\
\hline & & 2 & $0.0000^{-}$ & $0.0000^{-}$ & $0.0000^{-}$ & $0.0000^{+}$ & $0.0000^{+}$ & 122 \\
\hline & & 3 & $0.0000^{-}$ & $0.0000^{-}$ & $0.0000^{-}$ & $0.0000^{+}$ & $0.0000^{+}$ & 361 \\
\hline & \multirow[t]{3}{*}{2420} & 4 & $0.0000^{-}$ & $0.0000^{-}$ & $0.0000^{-}$ & $0.0000^{+}$ & $0.0000^{+}$ & 258 \\
\hline & & 5 & $0.0000^{-}$ & $0.0000^{-}$ & $0.0000^{-}$ & $0.0000^{+}$ & $0.0000^{-}$ & 413 \\
\hline & & 6 & $0.0168^{+}$ & $0.0000^{-}$ & $0.0000^{-}$ & $0.0000^{+}$ & $0.0000^{+}$ & 55 \\
\hline & \multirow[t]{3}{*}{2440} & 7 & $0.0000^{-}$ & $0.0000^{-}$ & $0.0000^{-}$ & $0.0000^{+}$ & $0.0000^{+}$ & 191 \\
\hline & & 8 & $0.0000^{-}$ & $0.0000^{-}$ & $0.0000^{-}$ & $0.0000^{+}$ & $0.0000^{+}$ & 165 \\
\hline & & 9 & $0.0000^{-}$ & $0.0000^{-}$ & $0.0000^{-}$ & $0.0000^{+}$ & $0.0000^{-}$ & 371 \\
\hline & \multirow[t]{3}{*}{2570} & 10 & $0.0000^{-}$ & $0.0000^{-}$ & $0.0000^{-}$ & $0.0000^{-}$ & $0.0000^{-}$ & 319 \\
\hline & & 11 & $0.0000^{-}$ & $0.0000^{-}$ & $0.0000^{-}$ & $0.0000^{+}$ & $0.0000^{+}$ & 287 \\
\hline & & 12 & $0.0000^{-}$ & $0.0000^{-}$ & $0.0000^{-}$ & $0.0000^{+}$ & $0.0000^{+}$ & 122 \\
\hline \multicolumn{9}{|c|}{ Amphistegina lessonii $t$-test $P$ values - at the $97.5 \%$ significance level } \\
\hline & \multirow[t]{3}{*}{2340} & 1 & $0.0000^{-}$ & $0.0000^{-}$ & $0.0000^{-}$ & $0.0004^{+}$ & $0.0000^{-}$ & 523 \\
\hline & & 2 & $0.0000^{-}$ & $0.0000^{-}$ & $0.0000^{-}$ & $0.2712^{\text {ns }}$ & $0.0000^{-}$ & 93 \\
\hline & & 3 & $0.0000^{-}$ & $0.0000^{-}$ & $0.0000^{-}$ & $0.3779^{\text {ns }}$ & $0.0000^{-}$ & 69 \\
\hline & \multirow[t]{3}{*}{2420} & 4 & $0.0004^{-}$ & $0.0221^{-}$ & $0.1126^{\mathrm{ns}}$ & $0.0000^{-}$ & $0.0000^{-}$ & 904 \\
\hline & & 5 & $0.0000^{-}$ & $0.0000^{-}$ & $0.0000^{-}$ & $0.0000^{-}$ & $0.0000^{-}$ & 393 \\
\hline & & 6 & $0.0000^{-}$ & $0.0000^{-}$ & $0.0000^{-}$ & $0.0000^{+}$ & $0.0000^{+}$ & 92 \\
\hline & \multirow[t]{3}{*}{2440} & 7 & $0.0000^{-}$ & $0.0000^{-}$ & $0.0000^{-}$ & $0.0647^{n s}$ & $0.0022^{+}$ & 611 \\
\hline & & 8 & $0.0000^{-}$ & $0.0000^{-}$ & $0.0000^{-}$ & $0.1374^{\mathrm{ns}}$ & $0.0000^{+}$ & 144 \\
\hline & & 9 & $0.0000^{-}$ & $0.0000^{-}$ & $0.0000^{-}$ & $0.0004^{+}$ & $0.1855^{\mathrm{ns}}$ & 505 \\
\hline & \multirow[t]{3}{*}{2570} & 10 & n.a. & n.a. & n.a. & n.a. & n.a. & 988 \\
\hline & & 11 & $0.0000^{-}$ & $0.0000^{-}$ & $0.0000^{-}$ & $0.0000^{+}$ & $0.0000^{+}$ & 373 \\
\hline & & 12 & $0.0000^{-}$ & $0.0000^{-}$ & $0.0000^{-}$ & $0.0253^{\text {ns }}$ & $0.2527^{\mathrm{ns}}$ & 104 \\
\hline
\end{tabular}

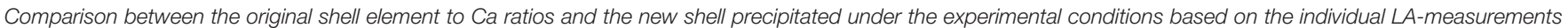

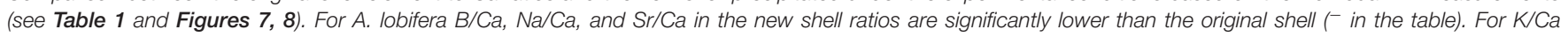
and $\mathrm{Mg} / \mathrm{Ca}$, the new shells show ratios that are significantly higher than the original shell (+ in the table). Only one result is not significantly different (Mg, ns in the table).

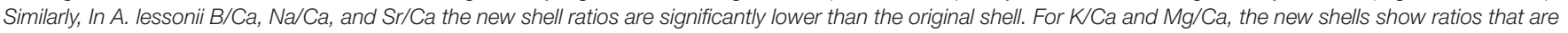
variable, slight lower or similar to the original shell. Accordingly, the differences are not significant for 8 out of the 66 values analyzed (5 in Mg, 2 in K and 1 in Sr). 


\section{Amphistegina lessonii}
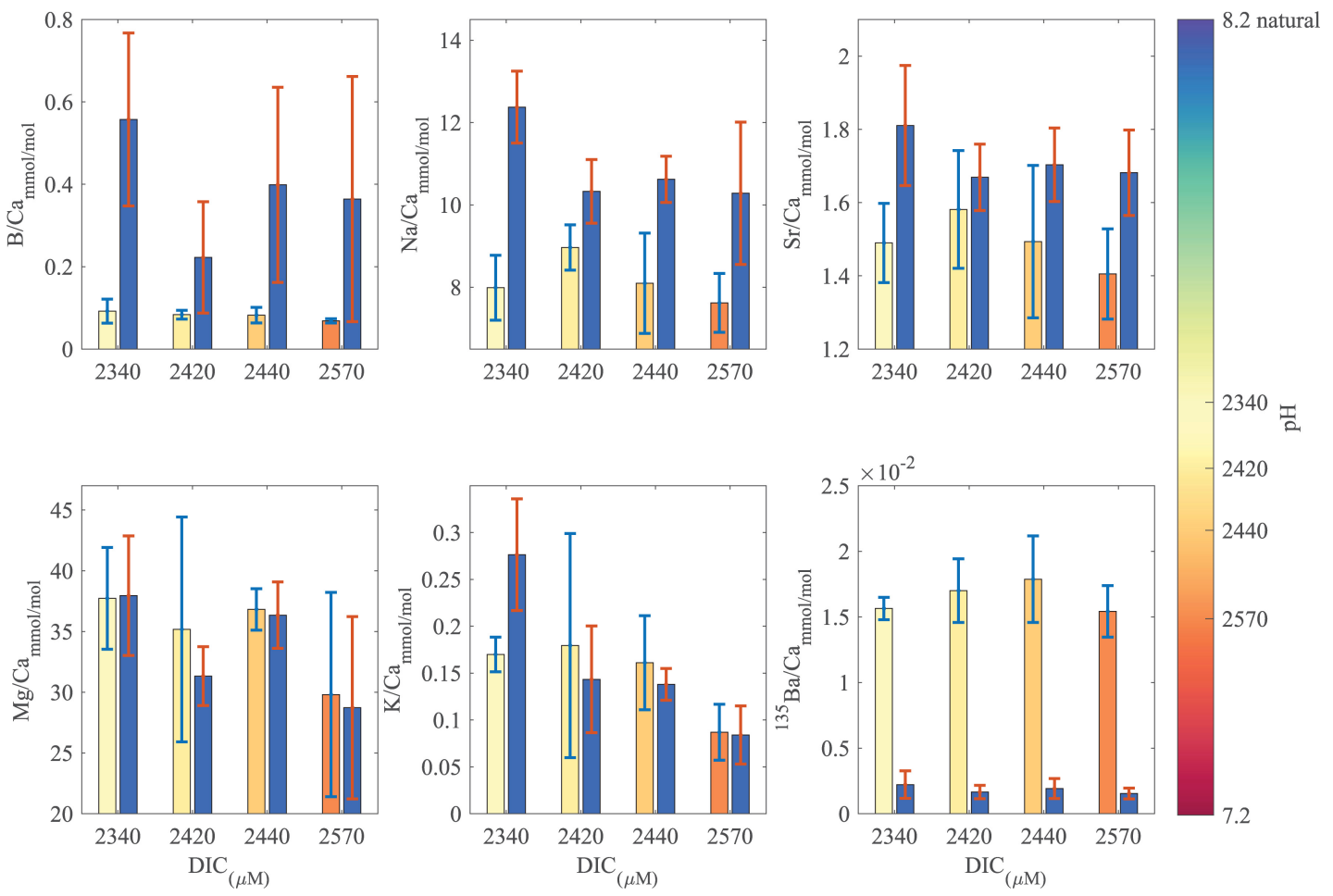

FIGURE 8 | Averages of El/Ca ratios of the natural-original shells Amphistegina lessonii in comparison with the newly grown shell under the DIC modified experimental conditions. For B/Ca, Na/Ca and $\mathrm{Sr} / \mathrm{Ca}$ the new shell ratios are significantly lower than the original shell. For K/Ca and Mg/Ca the new shells show ratios that are variable, slight lower or similar to the original shell (see Tables $\mathbf{1}, \mathbf{2}$ for statistics). ${ }^{135} \mathrm{Ba} / \mathrm{Ca}$ show the enrichment of the ${ }^{135} \mathrm{Ba}$ that was added to the culture media to mark the newly precipitated calcite. The numbers on the colored $\mathrm{pH}$ bar represent the experimental average DIC measurements during the experiments.

sharp. This probably occurs because of three main reasons: (1) The growth lines in the foraminifera shells in the knob area have a topography and are only semi parallel, especially for large ablation area of $4300 \mu \mathrm{m}^{2}$ used in this study. (2) The difference between the EPMA $1 \mu \mathrm{m}^{3}$ interaction volume (Erez, 2003) and the LA-ICPMS $\sim 700 \mu \mathrm{m}^{3}$ ablation volume per shot, which averages out and smooth the sharp peaks that seen by the EPMA. (3) The volume above the laser spot (the cup and tubing leading to the ICPMS) may causes some mixing between the layers and thus smooth out the original signal.

TABLE 3 | Logistic equation coefficients for the uptake of ${ }^{135} \mathrm{Ba}$ into the skeleton of $A$. lobifera and $A$. lessonii.

\section{A. lobifera}

\section{DIC}

Low

Intermediate low

Intermediate high

High

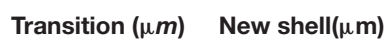

\subsection{1}

7.23

24.37

1.42

8.36

5.81

1.84

6.80

6.94

10.20

1.84

5.24

4.68
12.04

25.08

2.41

8.79

6.52

18.99

21.11

16.15

5.24

$\begin{array}{lll}51.30 & 0.23 & 2.52 \\ 59.94 & 1.14 & 2.10 \\ 43.22 & 1.30 & 2.01 \\ 45.49 & 0.25 & 2.39 \\ 36.56 & 0.36 & 2.23 \\ 64.62 & 1.06 & 1.89 \\ 51.72 & 0.34 & 2.77 \\ 53.14 & 0.30 & 2.37 \\ 36.42 & 0.20 & 2.23 \\ 45.91 & 1.05 & 2.12 \\ 45.49 & 0.37 & 1.90 \\ 57.96 & 0.49 & 2.63\end{array}$

Transition $(\mu \mathrm{m})$

11.48

2.27

1.13

6.66

11.48

1.56

7.23

3.12

7.65

0

6.09

0.99
A. Iessonii

$\begin{array}{cccc}\text { New shell }(\boldsymbol{\mu \mathbf { m } )} & \text { Old shell }(\boldsymbol{\mu \mathbf { m } )} & \boldsymbol{r} & \mathbf{K ~ 1 0 - 2} \\ 28.62 & 24.51 & 0.14 & 2 \\ 4.82 & 61.64 & 0.68 & 2 \\ 3.97 & 64.19 & 0.86 & 0.99 \\ 59.80 & 1.70 & 0.17 & 2.20 \\ 19.98 & 34.29 & 0.14 & 2 \\ 4.82 & 61.78 & 0.70 & 1.36 \\ 38.68 & 22.11 & 0.21 & 2.40 \\ 7.65 & 57.25 & 0.49 & 2 \\ 30.18 & 28.62 & 0.21 & 2 \\ 70 & \text { Nan } & \text { Inf } & 1.58 \\ 21.68 & 38.83 & 0.23 & 1.69 \\ 6.38 & 61.64 & 1.26 & 1.64\end{array}$




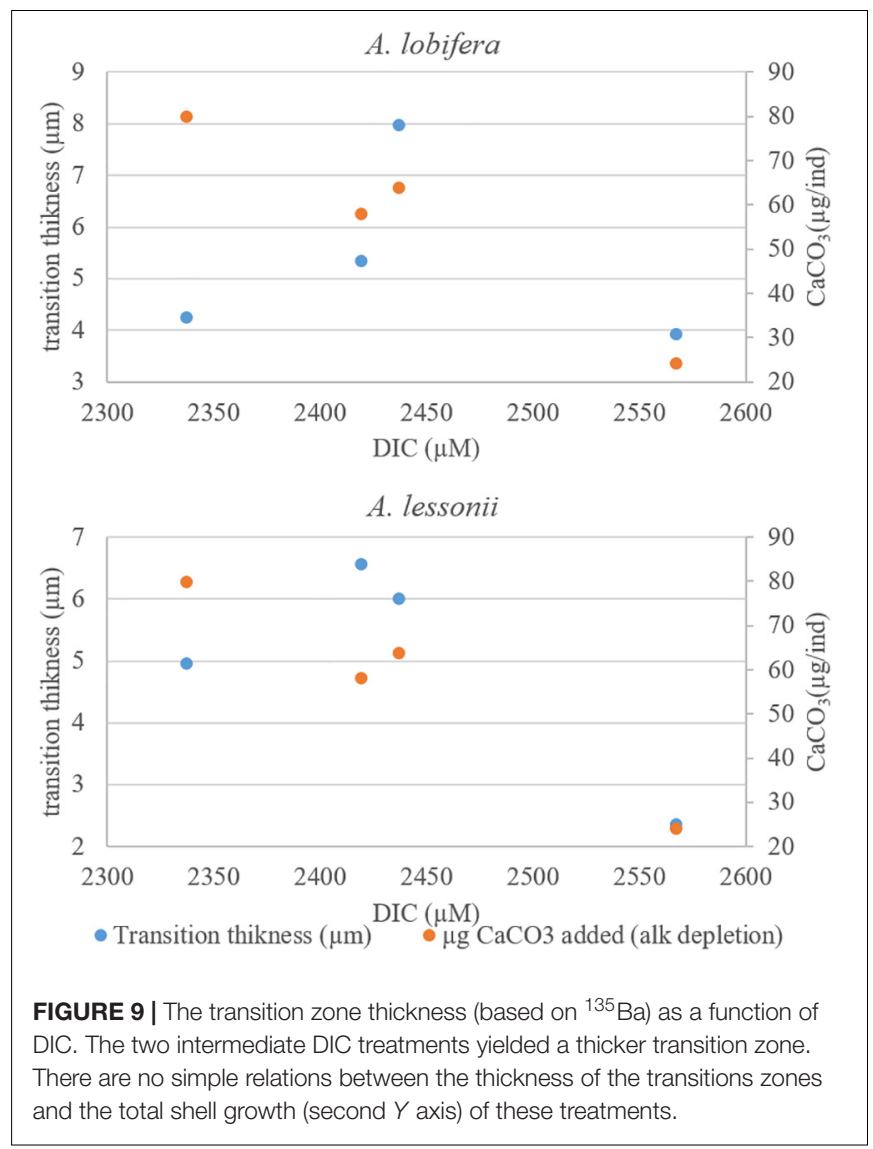

The element concentration between the old and new parts of the shells show trends that may be related to the elevated DIC. B/Ca, $\mathrm{Na} / \mathrm{Ca}$ and $\mathrm{Sr} / \mathrm{Ca}$ showing decrease with elevated DIC (Figures 2A-C) while $\mathrm{K} / \mathrm{Ca}, \mathrm{Mg} / \mathrm{Ca}$ and showing slight increase in $A$. lobifera (Figures 2D,E) that are reported before for other Ampnistegina species (van Dijk et al., 2017b). In A. lessonii B/Ca, $\mathrm{Na} / \mathrm{Ca}$, and $\mathrm{Sr} / \mathrm{Ca}$ also showing decrease with elevated DIC (Figures 3A-C) and in the $\mathrm{K} / \mathrm{Ca}, \mathrm{Mg} / \mathrm{Ca}$ we not see any significant change (Figures 3D,E). The $\mathrm{U}$ showing increase with the elevated DIC in both Ampnistegina species but it is not significant because only three specimens per treatment was ablated and there are large variation between specimens inside each group. To address this element properly more work need to be done to gain more statistics on the influence of the DIC on $\mathrm{U}$ concentration.

\section{The Effect of DIC on Intra-Shell Variability}

While the intrashell variability in foraminifera is widely described both in planktonic and benthic foraminifera, the source of these variations is not well understood. Erez and Bentov suggested that these variations are alternations of primary and secondary calcite (Erez, 2003; Bentov and Erez, 2005, 2006; Geerken et al., 2018) associated with the buildup of every new chamber (Figure 10). The primary calcite is associated with the organic matrix (often termed as the Primary Organic Membrane, POM or Primary Organic Sheet, POS) that forms the shape or scaffold (also called the anlage) for the newly precipitating chamber. The primary calcite is composed of very small nuclei of trace elements-rich crystals that are formed on both sides of the organic matrix (Bentov and Erez, 2005). The secondary calcite represents the well-known process of layering (or lamination) in bilamellar foraminifera (Reiss, 1957, 1959). This involves precipitation of thick low Mg layers of flat semi-hexagonal radially (c-axis) oriented calcite crystals that cover the newly precipitated primary calcite and forms the radial structure all over the exposed chambers, leaving the pores open, in the last exposed whorl of chambers. As such, the layered shell is composed of alternations of primary organic and trace element rich calcite (Erez, 2003; Bentov and Erez, 2005, 2006; Bonnin et al., 2019) and secondary calcite that comprise more than $95 \%$ of the shell mass that is lower in organic and trace element content. Note however, that in addition to the primary and secondary calcites there is a third layer termed the inner lining, which precipitates, inside every chamber (Figure 10). This layer is not represented in the knob area (investigated here) and was recently well described for planktonic foraminifera (Fehrenbacher et al., 2017). The reasons for the trace elements enrichment in the primary calcite is not known; however, we speculate that it may result from the interactions with the organic matrix, as suggested also in a by Erez (2003), Geerken et al. (2019). Additionally precipitation of Vaterite and possibly ACC precursors of the primary calcite may be rich in trace elements (Jochum et al., 2011; Jacob et al., 2017). In the planktonic foraminifera that add a new chamber every day (Spero, 1987; Eggins et al., 2004; Fehrenbacher et al., 2017) we propose that the $\mathrm{Mg}$ rich primary calcite is precipitated during the night as indeed well documented by these authors. In the large benthic foraminifera, each growth of new chamber with all its layering is occurring at slower rates of roughly once a week to 10 days (age dependent). In the present study we found that in addition to $\mathrm{Mg}, \mathrm{S}$, and $\mathrm{Na}$ (Erez, 2003; Bentov and Erez, 2005, 2006; Fehrenbacher et al., 2017), there is also enrichment in $\mathrm{K}$ and $\mathrm{Sr}$. Another possible explanation for the multi element high bands is that they represent precipitation from a semi-closed reservoir in which $\mathrm{Ca}$ is depleted relative to other ions (with distribution coefficient lower than 1) thus leading to an increase in their concentration relative to $\mathrm{Ca}$ (Elderfield et al., 1996). It is also possible that $\mathrm{Mg}$ is the key variable that changes its concentrations in the calcifying fluid and other elements are readily incorporated into the lattice due to the distortion of the crystal lattice (Mucci and Morse, 1983; Reeder et al., 1999). We cannot resolve with our data set the causes for these multi elemental cycles, but it should be mentioned that such cycles are also observed in other biomineralizing systems: clams (e.g,. Warter et al., 2018), corals (e.g., Vielzeuf et al., 2018) and others. Our observation that DIC did not affect the pattern of elemental cycles within the shells suggest that these variations are indeed an essential part of the calcification process that may be strongly biologically controlled and therefore are not influenced by the DIC. Recently Geerken et al. (2019) provided similar observations with respect to salinity 


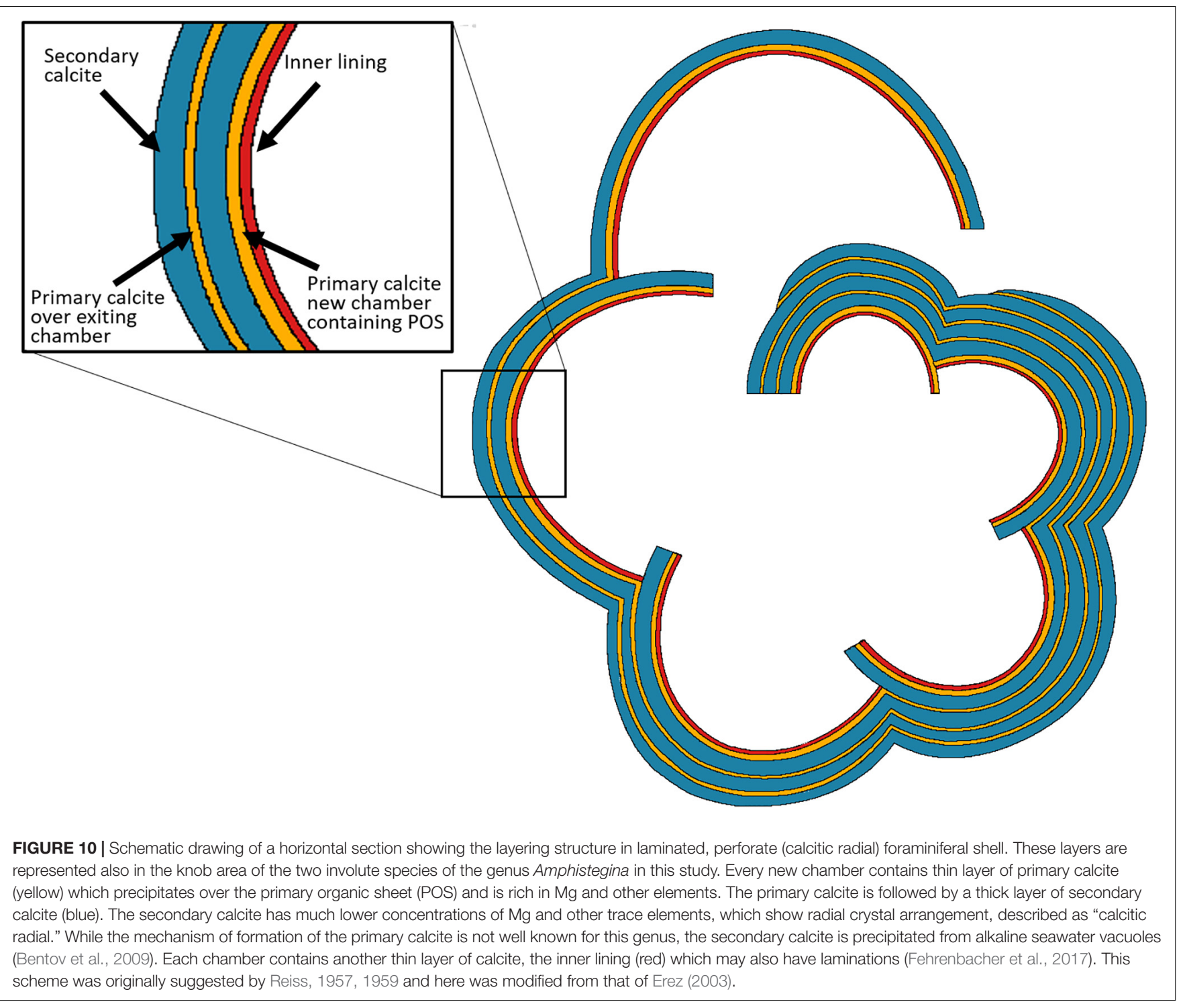

and temperature. While the patterns of intrashell variability did not change, the average ratios of elemets to calcium did change in response to DIC (Figures 7, 8 and Table 1). Because our observations are based on very few individuals, we do feel that further mechanistic interpretation of these data is beyond the scope of this paper.

\section{CONCLUSION}

Intra-shell chemical variability of the large benthic foraminifera A. lobifera and A. lessonii that were cultured under four high DIC concentrations (2340-2570 $\mu \mathrm{M})$ was measured in the knob area using LA-ICPMS. The LA profiles (in three specimens for each treatment per species) represent the growth history of last whorl of chambers $(\sim 10)$ in these two species. The knob displays alterations of Mg-rich and Mg-poor layers. The high $\mathrm{Mg}$ layers are also rich in $\mathrm{Na}, \mathrm{U}$ and $\mathrm{K}$ while $\mathrm{Sr}$ shows similar variability but out of phase with the $\mathrm{Mg}$. The high $\mathrm{Mg}$ layers are associated with the primary calcite while the low$\mathrm{Mg}$ layers of the secondary calcite have lower concentrations of minor and trace elements. The alternations between the high and low element bands in Amphistegina represent new chamber growth at a rate of $\sim$ once a week for these larger specimens. Furthermore, there is no significant influence of the DIC $\left(\mathrm{pCO}_{2}\right)$ changes on the alternation bands. On the other hand, the averages of some element to calcium ratios (B, $\mathrm{Na}$, and $\mathrm{Sr}$ ) are lower than the original shell at higher DIC while $\mathrm{Mg}$ and $\mathrm{K}$ are similar or slightly higher than the natural shell. ${ }^{135} \mathrm{Ba}$ was added to the culture media to mark the newly precipitated calcite. The dynamics of ${ }^{135} \mathrm{Ba}$ incorporation into the knob area is well describes using the logistic population growth function. We propose that this may represent the population of seawater vacuoles that bring the ions to the calcification site and are inherent to the biomineralization mechanism of these foraminifera. As for the intrashell cycles, we 
did not observe a correlation between the ${ }^{135} \mathrm{Ba}$ dynamics and the DIC treatments.

\section{AUTHOR CONTRIBUTIONS}

JE designed and directed the study. AL performed the growth experiments and analyzed the data. WM performed LA-ICPMS analysis and processing. AL, JE, and WM wrote the manuscript.

\section{FUNDING}

This work was supported by Israel Science Foundation grants ISF grants $551 / 10$ and $790 / 16$ to JE.

\section{REFERENCES}

Allen, K. A., Hönisch, B., Eggins, S. M., Haynes, L. L., Rosenthal, Y., and Yu, J. (2016). Trace element proxies for surface ocean conditions: a synthesis of culture calibrations with planktic foraminifera. Geochim. Cosmochim. Acta 193, 197-221. doi: 10.1016/j.gca.2016.08.015

Barker, S., and Elderfield, H. (2002). Foraminiferal calcification response to glacialinterglacial changes in atmospheric $\mathrm{Co}_{2}$. Science 297, 833-836. doi: 10.1126/ science. 1072815

Bentov, S., Brownlee, C., and Erez, J. (2009). The role of seawater endocytosis in the biomineralization process in calcareous foraminifera. Proc. Natl. Acad. Sci. U.S.A. 106, 21500-21504. doi: 10.1073/pnas.0906636106

Bentov, S., and Erez, J. (2005). Novel observations on biomineralization processes in foraminifera and implications for $\mathrm{Mg} / \mathrm{Ca}$ ratio in the shells. Geology 33, 841-844. doi: 10.1130/G21800.1

Bentov, S., and Erez, J. (2006). Impact of biomineralization processes on the $\mathrm{Mg}$ content of foraminiferal shells: a biological perspective. Geochem. Geophys. Geosyst. 7, 1010-1029. doi: 10.1029/2005GC001015

Bonnin, E. A., Zhu, Z., Fehrenbacher, J. S., Russell, A. D., Hönisch, B., Spero, H. J., et al. (2019). Submicron sodium banding in cultured planktic foraminifera shells. Geochim. Cosmochim. Acta 253, 127-141. doi: 10.1016/j.gca.2019. 03.024

Branson, O., Kaczmarek, K., Redfern, S. A. T., Misra, S., Langer, G., Tyliszczak, T., et al. (2015). The coordination and distribution of B in foraminiferal calcite. Earth Planet. Sci. Lett. 416, 67-72. doi: 10.1016/j.epsl.2015.02.006

Climap project (1976). The surface of the ice-age Earth. Science 191, 1131-1137.

Crowley, T. J. (2000). CLIMAP SSTs re-revisited. Clim. Dyn. 16, 241-255. doi: 10.1007/s003820050325

Davis, C. V., Fehrenbacher, J. S., Benitez-Nelson, C., and Thunell, R. C. (2020). Trace element heterogeneity across individual planktic foraminifera from the modern Cariaco basin. J. Foraminifer. Res. 50, 204-218. doi: 10.2113/gsjfr.50.2. 204

de Nooijer, L. J., Spero, H. J., Erez, J., Bijma, J., and Reichart, G. J. (2014). Biomineralization in perforate foraminifera. Earth Sci. Rev. 135, 48-58. doi: 10.1016/j.earscirev.2014.03.013

de Nooijer, L. J., Toyofuku, T., and Kitazato, H. (2009). Foraminifera promote calcification by elevating their intracellular pH. Proc. Natl. Acad. Sci. U.S.A. 106, 15374-15378. doi: 10.1073/pnas.0904306106

Dias, B. B., Hart, M. B., Smart, C. W., and Hall-Spencer, J. M. (2010). Modern seawater acidification: the response of foraminifera to high- $\mathrm{CO}_{2}$ conditions in the Mediterranean Sea. J. Geol. Soc. Lond. 167, 843-846. doi: 10.1144/001676492010-050

Dissard, D., Nehrke, G., Reichart, G. J., and Bijma, J. (2010). The impact of salinity on the $\mathrm{Mg} / \mathrm{Ca}$ and $\mathrm{Sr} / \mathrm{Ca}$ ratio in the benthic foraminifera Ammonia tepida: results from culture experiments. Geochim. Cosmochim. Acta 74, 928-940. doi: 10.1016/J.GCA.2009.10.040

Eggins, S., De Deckker, P., and Marshall, J. (2003). Mg/Ca variation in planktonic foraminifera tests: implications for reconstructing -palaeo-seawater

\section{ACKNOWLEDGMENTS}

We thank Dr. David Evans who helped with the analysis of the foraminifera using the LA-ICPMS. We thank the HUJI students Matan Yona, Hagar Hauzer, and Elana Palaria for their help in the field collections and the laboratory experiments.

\section{SUPPLEMENTARY MATERIAL}

The Supplementary Material for this article can be found online at: https://www.frontiersin.org/articles/10.3389/feart. 2019.00247/full\#supplementary-material

temperature and habitat migration. Earth Planet. Sci. Lett. 212, 291-306. doi: 10.1016/S0012-821X(03)00283-8

Eggins, S. M., Sadekov, A., and De Deckker, P. (2004). Modulation and daily banding of $\mathrm{Mg} / \mathrm{Ca}$ in Orbulina universa tests by symbiont photosynthesis and respiration: a complication for seawater thermometry? Earth Planet. Sci. Lett. 225, 411-419. doi: 10.1016/j.epsl.2004.06.019

Elderfield, H., Bertram, C. J., and Erez, J. (1996). A biomineralization model for the incorporation of trace elements into foraminiferal calciumcarbonate. Earth Planet. Sci. Lett. 142, 409-423. doi: 10.1016/0012-821x(96)00105-7

Elderfield, H., Vautravers, M., and Cooper, M. (2002). The relationship between shell size and $\mathrm{Mg} / \mathrm{Ca}, \mathrm{Sr} / \mathrm{Ca}, \delta 18 \mathrm{O}$, and $\delta 13 \mathrm{C}$ of species of planktonic foraminifera. Geochem. Geophys. Geosyst. 3, 1-13. doi: 10.1029/2001GC000194

Emiliani, C., and Shackleton, N. J. (1974). The Brunhes epoch: isotopic paleotemperatures and geochronology. Science 183, 511-514. doi: 10.1126/ science.183.4124.511

Erez, J. (1978). Vital effect on stable-isotope composition seen in foraminifera and coral skeletons. Nature 273, 199-202. doi: 10.1038/273199a0

Erez, J. (2003). The source of ions for biomineralization in Foraminifera and their implications for paleoceanographic proxies. Rev. Mineral. Geochem. 54, 115-149. doi: 10.2113/0540115

Evans, D., Erez, J., Oron, S., and Müller, W. (2015). Mg/Ca-temperature and seawater-test chemistry relationships in the shallow-dwelling large benthic foraminifera Operculina ammonoides. Geochim. Cosmochim. Acta 148, 325342. doi: 10.1016/j.gca.2014.09.039

Evans, D., Müller, W., and Erez, J. (2018). Assessing foraminifera biomineralisation models through trace element data of cultures under variable seawater chemistry. Geochim. Cosmochim. Acta 236, 198-217. doi: 10.1016/j.gca.2018.02. 048

Evans, D., Wade, B. S., Henehan, M., Erez, J., and Müller, W. (2016). Revisiting carbonate chemistry controls on planktic foraminifera $\mathrm{Mg} / \mathrm{Ca}$ : implications for sea surface temperature and hydrology shifts over the Paleocene-Eocene Thermal Maximum and Eocene-Oligocene transition. Clim. Past 12, 819-835. doi: $10.5194 / \mathrm{cp}-12-819-2016$

Evans, D., and Müller, W. (2018). Automated extraction of a five-year LA-ICP-MS trace element data set of ten common glass and carbonate reference materials: long-term data quality, optimisation and laser cell homogeneity. Geostand. Geoanal. Res. 42, 159-188. doi: 10.1111/ggr.12204

Fehrenbacher, J. S., Russell, A. D., Davis, C. V., Gagnon, A. C., Spero, H. J., Cliff, J. B., et al. (2017). Link between light-triggered Mg-banding and chamber formation in the planktic foraminifera Neogloboquadrina dutertrei. Nat. Commun. 8:15441. doi: 10.1038/ncomms 15441

Foster, G. L., and Rae, J. W. B. (2016). Reconstructing ocean pH with boron isotopes in foraminifera. Annu. Rev. Earth Planet. Sci. 44, 207-237. doi: 10.1146/ annurev-earth-060115-012226

Friedrich, O., Schiebel, R., Wilson, P. A., Weldeab, S., Beer, C. J., Cooper, M. J., et al. (2012). Influence of test size, water depth, and ecology on $\mathrm{Mg} / \mathrm{Ca}, \mathrm{Sr} / \mathrm{Ca}, \delta 18 \mathrm{O}$ and $\delta 13 \mathrm{C}$ in nine modern species of planktic foraminifers. Earth Planet. Sci. Lett. 319-320, 133-145. doi: 10.1016/j.epsl.2011.12.002 
Fujita, K., Hikami, M., Suzuki, A., Kuroyanagi, A., Sakai, K., Kawahata, H., et al. (2011). Effects of ocean acidification on calcification of symbiont-bearing reef foraminifers. Biogeosciences 8, 2089-2098. doi: 10.5194/bg-8-2089-2011

Geerken, E., de Nooijer, L. J., Roepert, A., Polerecky, L., King, H. E., and Reichart, G. J. (2019). Element banding and organic linings within chamber walls of two benthic foraminifera. Sci. Rep. 9:3598. doi: 10.1038/s41598-019-40298-y

Geerken, E., Jan de Nooijer, L., van DIjk, I., and Reichart, G. J. (2018). Impact of salinity on element incorporation in two benthic foraminiferal species with contrasting magnesium contents. Biogeosciences 15, 2205-2218. doi: 10.5194/ bg-15-2205-18

Gray, W. R., and Evans, D. (2019). Nonthermal influences on $\mathrm{Mg} / \mathrm{Ca}$ in planktonic foraminifera: a review of culture studies and application to the last glacial maximum. Paleoceanogr. Paleoclimatol. 34, 306-315. doi: 10.1029/ 2018PA003517

Griffiths, N., Müller, W., Johnson, K. G., and Aguilera, O. A. (2013). Evaluation of the effect of diagenetic cements on element/Ca ratios in aragonitic Early Miocene ( $16 \mathrm{Ma}$ ) Caribbean corals: implications for "deep-time" palaeoenvironmental reconstructions. Palaeogeogr. Palaeoclimatol. Palaeoecol. 369, 185-200. doi: 10.1016/j.palaeo.2012.10.018

Gussone, N., Filipsson, H. L., and Kuhnert, H. (2016). Mg/Ca, Sr/Ca and Ca isotope ratios in benthonic foraminifers related to test structure, mineralogy and environmental controls. Geochim. Cosmochim. Acta 173, 142-159. doi: 10.1016/j.gca.2015.10.018

Hall, J. M., and Chan, L. H. (2004). Li/Ca in multiple species of benthic and planktonic foraminifera: thermocline, latitudinal, and glacial-interglacial variation. Geochim. Cosmochim. Acta 68, 529-545. doi: 10.1016/S00167037(00)00451-4

Hathorne, E. C., James, R. H., and Lampitt, R. S. (2009). Environmental versus biomineralization controls on the intratest variation in the trace element composition of the planktonic foraminifera G. inflata and G. scitula. Paleoceanography 24, 1-14. doi: 10.1029/2009PA001742

Hauzer, H., Evans, D., Müller, W., Rosenthal, Y., and Erez, J. (2018). Calibration of $\mathrm{Na}$ partitioning in the calcitic foraminifer Operculina ammonoides under variable Ca concentration: toward reconstructing past seawater composition. Earth Planet. Sci. Lett. 497, 80-91. doi: 10.1016/j.epsl.2018.06.004

Holland, K., Eggins, S. M., Hönisch, B., Haynes, L. L., and Branson, O. (2017). Calcification rate and shell chemistry response of the planktic foraminifer Orbulina universa to changes in microenvironment seawater carbonate chemistry. Earth Planet. Sci. Lett. 464, 124-134. doi: 10.1016/j.epsl.2017.02.018

Hori, M., Shirai, K., Kimoto, K., Kurasawa, A., Takagi, H., Ishida, A., et al. (2018). Chamber formation and trace element distribution in the calcite walls of laboratory cultured planktonic foraminifera (Globigerina bulloides and Globigerinoides ruber). Mar. Micropaleontol. 140, 46-55. doi: 10.1016/j. marmicro.2017.12.004

Jacob, D. E., Wirth, R., Agbaje, O. B. A., Branson, O., and Eggins, S. M. (2017). Planktic foraminifera form their shells via metastable carbonate phases. Nat. Commun. 8, 1-8. doi: 10.1038/s41467-017-00955-0

Jochum, K. P., Weis, U., Stoll, B., Kuzmin, D., Yang, Q., Raczek, I., et al. (2011). Determination of reference values for NIST SRM 610-617 glasses following ISO guidelines. Geostand. Geoanal. Res. 35, 397-429. doi: 10.1111/j.1751-908X. 2011.00120.x

Jonkers, L., Buse, B., Brummer, G. J. A., and Hall, I. R. (2016). Chamber formation leads to $\mathrm{Mg} / \mathrm{Ca}$ banding in the planktonic foraminifer Neogloboquadrina pachyderma. Earth Planet. Sci. Lett. 451, 177-184. doi: 10.1016/j.epsl.2016.07. 030

Katz, M. E., Cramer, B. S., Franzese, A., Hönisch, B., Miller, K. G., Rosenthal, Y., et al. (2010). Traditional and emerging geochemical proxies in foraminifera. J. Foraminifer. Res. 40, 165-192. doi: 10.2113/gsjfr.40.2.165

Keul, N., Langer, G., De Nooijer, L. J., Nehrke, G., Reichart, G. J., and Bijma, J. (2013). Incorporation of uranium in benthic foraminiferal calcite reflects seawater carbonate ion concentration. Geochem. Geophys. Geosyst. 14, 102-111. doi: 10.1029/2012GC004330

Keul, N., Langer, G., Thoms, S., de Nooijer, L. J., Reichart, G. J., and Bijma, J. (2017). Exploring foraminiferal $\mathrm{Sr} / \mathrm{Ca}$ as a new carbonate system proxy. Geochim. Cosmochim. Acta 202, 374-386. doi: 10.1016/j.gca.2016.11.022

Kisakürek, B., Eisenhauer, A., Böhm, F., Garbe-Schönberg, D., and Erez, J. (2008). Controls on shell $\mathrm{Mg} / \mathrm{Ca}$ and $\mathrm{Sr} / \mathrm{Ca}$ in cultured planktonic foraminiferan,
Globigerinoides ruber (white). Earth Planet. Sci. Lett. 273, 260-269. doi: 10. 1016/j.epsl.2008.06.026

Kuroyanagi, A., Kawahata, H., Suzuki, A., Fujita, K., and Irie, T. (2009). Impacts of ocean acidification on large benthic foraminifers: results from laboratory experiments. Mar. Micropaleontol. 73, 190-195. doi: 10.1016/j.marmicro.2009. 09.003

Lea, D. W. (1999). “Trace elements in foraminiferal calcite," in Modern Foraminifera, (Dordrecht: Springer Netherlands), 259-277. doi: 10.1007/0-30648104-9_15

Lea, D., and Boyle, E. (1989). Barium content of benthic foraminifera controlled by bottom-water composition. Nature 338, 751-753. doi: 10.1038/338751a0

Lear, C. H., Rosenthal, Y., and Slowey, N. (2002). Benthic foraminiferal Mg/Capaleothermometry: a revised core-top calibration. Geochim. Cosmochim. Acta 66, 3375-3387. doi: 10.1016/S0016-7037(02)00941-9

Lear, C. H., Rosenthal, Y., and Wright, J. D. (2003). The closing of a seaway: ocean water masses and global climate change. Earth Planet. Sci. Lett. 210, 425-436. doi: 10.1016/S0012-821X(03)00164-X

McIntyre-Wressnig, A., Bernhard, J. M., McCorkle, D. C., and Hallock, P. (2013). Non-lethal effects of ocean acidification on the symbiont-bearing benthic foraminifer Amphistegina gibbosa. Mar. Ecol. Prog. Ser. 472, 45-60. doi: 10. 3354/meps09918

Mucci, A., and Morse, J. W. (1983). The incorporation of $\mathrm{Mg} 2+$ and $\mathrm{Sr} 2+$ into calcite overgrowths: influences of growth rate and solution composition. Geochim. Cosmochim. Acta 47, 217-233. doi: 10.1016/0016-7037(83)90135-7

Müller, W., Shelley, M., Miller, P., and Broude, S. (2009). Initial performance metrics of a new custom-designed ArF excimer LA-ICPMS system coupled to a two-volume laser-ablation cell. J. Anal. At. Spectrom. 24, 209-214. doi: $10.1039 / \mathrm{b} 805995 \mathrm{k}$

Nehrke, G., Keul, N., Langer, G., de Nooijer, L. J., Bijma, J., and Meibom, A. (2013). A new model for biomineralization and trace-element signatures of Foraminifera tests. Biogeosciences 10, 6759-6767. doi: 10.5194/bg-10-67592013

Nürnberg, D., Bijma, J., and Hemleben, C. (1996). Assessing the reliability of magnesium in foraminiferal calcite as a proxy for water mass temperatures. Geochim. Cosmochim. Acta 60, 803-814. doi: 10.1016/0016-7037(95)00446-7

Nürnberg, D. (2000). Taking the temperature of past ocean surfaces. Science 289, 1698-1699. doi: 10.1126/science.289.5485.1698

Paton, C., Hellstrom, J., Paul, B., Woodhead, J., and Hergt, J. (2011). Iolite: freeware for the visualisation and processing of mass spectrometric data. J. Anal. At. Spectrom. 26, 2508-2518. doi: 10.1039/C1JA10172B

Raitzsch, M., Hathorne, E. C., Kuhnert, H., Groeneveld, J., and Bickert, T. (2011a). Modern and late pleistocene B/Ca ratios of the benthic foraminifer Planulina wuellerstorfidetermined with laser ablation ICP-MS. Geology 39, 1039-1042. doi: 10.1130/G32009.1

Raitzsch, M., Kuhnert, H., Hathorne, E. C., Groeneveld, J., and Bickert, T. (2011b). $\mathrm{U} / \mathrm{Ca}$ in benthic foraminifers: a proxy for the deep-sea carbonate saturation. Geochem. Geophys. Geosys. 12, 1-12. doi: 10.1029/2010GC003344

Rathmann, S., Hess, S., Kuhnert, H., and Mulitza, S. (2004). Mg/Ca ratios of the benthic foraminifera Oridorsalis umbonatus obtained by laser ablation from core top sediments: relationship to bottom water temperature. Geochem. Geophys. Geosyst. 5, 1-10. doi: 10.1029/2004GC000808

Reeder, R. J., Lamble, G. M., and Northrup, P. A. (1999). XAFS study of the coordination and local relaxation around $\mathrm{Co} 2+, \mathrm{Zn} 2+, \mathrm{Pb} 2+$, and $\mathrm{Ba} 2+$ trace elements in calcite. Am. Mineral. 84, 1049-1060. doi: 10.2138/am-1999-7-807

Reichart, G. J., Jorissen, F., Anschutz, P., and Mason, P. R. D. (2003). Single foraminiferal test chemistry records the marine environment. Geology 31, 355-358.

Reiss, Z. (1957). The bilamellidea, nov. superfamily, and remarks on cretaceous globorotaliids. Contrib. Cushman Found. Foraminifer. Res. 8, 127-145.

Reiss, Z. (1959). The wall-structure of Cibicides, Planulina, Gyroidinoides, and Globorotalites. Micropaleontology 5, 355-357.

Reiss, Z., and Hottinger, L. (1984). The Gulf of Aqaba: Ecological Micropaleontology. Berlin: Springer Science \& Business Media. doi: 10.1007/978-3-642-69787-6

Rollion-Bard, C., Erez, J., and Zilberman, T. (2008). Intra-shell oxygen isotope ratios in the benthic foraminifera genus Amphistegina and the influence of seawater carbonate chemistry and temperature on this ratio. Geochim. Cosmochim. Acta 72, 6006-6014. doi: 10.1016/J.GCA.2008.09.013 
Rosenthal, Y., Boyle, E. A., and Slowey, N. (1997). Temperature control on the incorporation of magnesium, strontium, fluorine, and cadmium into benthic foraminiferal shells from little bahama bank: prospects for thermocline paleoceanography. Geochim. Cosmochim. Acta 61, 3633-3643. doi: 10.1016/ S0016-7037(97)00181-6

Rosenthal, Y., Lear, C. H., Oppo, D. W., and Linsley, B. K. (2006). Temperature and carbonate ion effects on $\mathrm{Mg} / \mathrm{Ca}$ and $\mathrm{Sr} / \mathrm{Ca}$ ratios in benthic foraminifera: Aragonitic species Hoeglundina elegans. Paleoceanography 21:A1007. doi: 10. 1029/2005PA001158

Russell, A. D., Hönisch, B., Spero, H. J., and Lea, D. W. (2004). Effects of seawater carbonate ion concentration and temperature on shell $\mathrm{U}, \mathrm{Mg}$, and $\mathrm{Sr}$ in cultured planktonic foraminifera. Geochim. Cosmochim. Acta 68, 4347-4361. doi: 10. 1016/j.gca.2004.03.013

Sanyal, A., Hemming, N. G., Broecker, W. S., Lea, D. W., Spero, H. J., and Hanson, G. N. (1996). Oceanic pH control on the boron isotopic composition of foraminifera: evidence from culture experiments. Paleoceanography 11, 513517. doi: 10.1029/96PA01858

Spero, H. J. (1987). Symbiosis in the Planktonic Foraminifer, orbulina universa, and the isolation of its symbiotic Dinoflagellate, Gymnodinium Béii Sp. Nov. J. Phycol. 23, 307-317. doi: 10.1111/j.1529-8817.1987.tb0 4139.x

Spero, H. J., Bijma, J., Lea, D. W., Bemis, B. E., and Bernis, B. E. (1997). Effect of seawater carbonate concentration on foraminiferal carbon and oxygen isotopes. Nature 390, 497-500. doi: 10.1038/37333

Spero, H. J., Eggins, S. M., Russell, A. D., Vetter, L., Kilburn, M. R., and Hönisch, B. (2015). Timing and mechanism for intratest $\mathrm{Mg} / \mathrm{Ca}$ variability in a living planktic foraminifer. Earth Planet. Sci. Lett. 409, 32-42. doi: 10.1016/j.epsl.2014. 10.030

ter Kuile, B., Erez, J., and Padan, E. (1989). Mechanisms for the uptake of inorganic carbon by two species of symbiont-bearing foraminifera. Mar. Biol. 103, 241-251. doi: 10.1007/BF00543354

van Dijk, I., de Nooijer, L. J., Boer, W., and Reichart, G. J. (2017a). Sulfur in foraminiferal calcite as a potential proxy for seawater carbonate ion concentration. Earth Planet. Sci. Lett. 470, 64-72. doi: 10.1016/j.epsl.2017.04. 031

van Dijk, I., Nooijer de, L. J., and Reichart, G. J. (2017b). Trends in element incorporation in hyaline and porcelaneous foraminifera as a function of $\mathrm{pCO}_{2}$. Biogeosciences 14, 497-510. doi: 10.5194/bg-14-497-2017

van Dijk, I., Mouret, A., Cotte, M., Le Houedec, S., Oron, S., Reichart, G. J., et al. (2019). Chemical Heterogeneity of $\mathrm{Mg}, \mathrm{Mn}, \mathrm{Na}, \mathrm{S}$, and $\mathrm{Sr}$ in Benthic Foraminiferal Calcite. Front. Earth Sci. 7:281. doi: 10.3389/feart.2019.00281

Verhulst, P. J. (1938). Notice sur la lois Que la population Suit Dans sons accroissenment. Corresp. Mathématique Phys. 10, 113-121.
Vielzeuf, D., Gagnon, A., Ricolleau, A., Devidal, J.-L., Balme-Heuze, C., Yahiaoui, N., et al. (2018). Growth kinetics and distribution of trace elements in precious corals. Front. Earth Sci. 6:167. doi: 10.3389/feart.2018.00167

Vogel, N., and Uthicke, S. (2012). Calcification and photobiology in symbiontbearing benthic foraminifera and responses to a high $\mathrm{CO}_{2}$ environment. J. Exp. Mar. Biol. Ecol. 424, 15-24. doi: 10.1016/j.jembe.2012.05.008

Warter, V., Erez, J., and Müller, W. (2018). Environmental and physiological controls on daily trace element incorporation in Tridacna crocea from combined laboratory culturing and ultra-high resolution LA-ICP-MS analysis. Palaeogeogr. Palaeoclimatol. Palaeoecol. 496, 32-47. doi: 10.1016/j.palaeo.2017. 12.038

Wit, J. C., de Nooijer, L. J., Wolthers, M., and Reichart, G. J. (2013). A novel salinity proxy based on na incorporation into foraminiferal calcite. Biogeosciences 10, 6375-6387. doi: 10.5194/bg-10-6375-2013

Woodhead, J. D., Hellstrom, J., Hergt, J. M., Greig, A., and Maas, R. (2007). Isotopic and elemental imaging of geological materials by laser ablation inductively coupled plasma-mass spectrometry. Geostand. Geoanal. Res. 31, 331-343. doi: 10.1111/j.1751-908X.2007.00104.x

Yu, J., and Elderfield, H. (2007). Benthic foraminiferal B/Ca ratios reflect deep water carbonate saturation state. Earth Planet. Sci. Lett. 258, 73-86. doi: 10. 1016/j.epsl.2007.03.025

Yu, J., and Elderfield, H. (2008). Mg/Ca in the benthic foraminifera Cibicidoides wuellerstorfi and Cibicidoides mundulus: temperature versus carbonate ion saturation. Earth Planet. Sci. Lett. 276, 129-139. doi: 10.1016/j.epsl.2008.09.015

Yu, J., Elderfield, H., Jin, Z., Tomascak, P., and Rohling, E. J. (2014). Controls on $\mathrm{Sr} / \mathrm{Ca}$ in benthic foraminifera and implications for seawater Sr/Ca during the late Pleistocene. Quat. Sci. Rev. 98, 1-6. doi: 10.1016/J.QUASCIREV.2014.b05.018

Zeebe, R. E., Bijma, J., Hönisch, B., Sanyal, A., Spero, H. J., and Wolf-gladrow, D. A. (2008). Vital effects and beyond: a modelling perspective on developing palaeoceanographical proxy relationships in foraminifera. Geol. Soc. Spec. Publ. 303, 45-58. doi: 10.1144/SP303.4

Conflict of Interest: The authors declare that the research was conducted in the absence of any commercial or financial relationships that could be construed as a potential conflict of interest.

Copyright (C) 2019 Levi, Müller and Erez. This is an open-access article distributed under the terms of the Creative Commons Attribution License (CC BY). The use, distribution or reproduction in other forums is permitted, provided the original author(s) and the copyright owner(s) are credited and that the original publication in this journal is cited, in accordance with accepted academic practice. No use, distribution or reproduction is permitted which does not comply with these terms. 